\title{
LA LAICIDAD POSITIVA COMO GARANTÍA INSTITUCIONAL DE LA PRESENCIA DE SÍMBOLOS RELIGIOSOS Y CULTURALES EN LOS CENTROS DOCENTES PÚBLICOS ${ }^{1}$
}

\author{
Salvador PéREz Álvarez \\ Departamento de Derecho Eclesiástico del Estado \\ Facultad de Derecho de ka UNED \\ sperez@der.uned.es
}

\begin{abstract}
RESUMEN
El reconocimiento de la igual libertad ideológica a todos los ciudadanos y los flujos migratorios de nacionales de terceros Estados con señas de identidad diferenciadas ha dado lugar a una sociedad española mucho más secularizada pero, al mismo tiempo, más plural desde los puntos de vista ideológico y/o cultural. Un claro reflejo de esta realidad es la diversidad religiosa latente en las aulas de los centros docentes públicos, cuya gestión debe ser atendida por las autoridades educativas por presión de la laicidad positiva como garantía institucional del ideario educativo constitucional español.
\end{abstract}

Palabras clave: libertad ideológica, laicidad positiva, derecho a la educación, ideario educativo constitucional, símbolos religiosos, símbolos culturales, centros docentes públicos.

\section{ABSTRACT}

The fact that the equality of beliefs of all citizens and the migration flux of other foreign nationals with remarkable identity signs is now admitted in Spain has led to a much more secularized but, at the same time, plural society, from an ideological or cultural point of view. A clear proof of such reality is the different religions cohabitating in public schools, managed by education authorities by means of pressure of positive laicism as institutional guarantee for the Spanish constitutional educative guidelines.

Keywords: Freedom of beliefs, positive laicism, right to education, constitutional education guidelines, religious symbols, cultural symbols, public education centres.

${ }_{1}^{1}$ Trabajo realizado en el marco del Proyecto de Investigación dirigido por Ana FERNÁNDEZ-CORONADO, «Integra2. Claves jurídicas: derecho a la educación, diversidad religiosa y cohesión social», referencia: DER2015-63640-P. 


\section{ZUSAMMENFASSUNG}

Die Anerkennung der gleichen ideologischen Freibeit aller Bürger und die Migrantenströme von Staatsbürgern aus Drittstaaten mit unterschiedlichen Identitäten baben dazu gefübrt, dass die spanische Gesellschaft säkularer, aber auch gleichzeitig, vom ideologischen und kulturellen Standpunkt aus betrachtet, pluraler wurde. Ein klares Abbild dieser Situation ist die religiöse Vielfalt, die in den öffentlichen Lebranstalten zu finden ist. Die Regelung dieser kulturellen Fragen sollte durch den Druck der positiven Laizität auf die Unterrichtsanstalten erfolgen, damit das in der Verfassung grundgelegte erzieherische Gedankengut wirksam zum Ausdruck kommen kann.

Schlüsselwörter: Ideologische Freiheit, Positive Laizität, Recht auf Erziehung, in der Verfassung grundgelegtes erzieherisches Gedankengut, religöse Symbole, kulturelle Symbole, öffentliche Lehranstalten.

SUMARIO: I. INTRODUCCION.-II. LA LAICIDAD POSITIVA COMO GARANTÍA INSTITUCIONAL DEL SISTEMA EDUCATIVO PÚBLICO. ALGUNAS CUESTIONES PARTICULARES.-1. La laicidad positiva como garantía institucional del pluralismo ideológico y religioso.-2. La laicidad positiva como garante de la libertad para formar en y para la libertad la propia ideología o conciencia en el sistema educativo público.--III. LAICIDAD POSITIVA Y SIMBOLOGÍA EN LOS CENTROS DOCENTES PÚBLICOS.-1. Delimitación conceptual: símbolos culturales y símbolos religiosos.-2. Vertiente objetiva de la laicidad positiva y uso institucional de símbolos culturales o religiosos en los centros docentes públicos.-3. Vertiente subjetiva de la laicidad positiva y el uso de símbolos como manifestaciones de las señas de identidad religiosas y/o culturales en los centros docentes públicos.-IV. A MODO DE CONCLUSIÓN.

\section{INTRODUCCIÓN}

La entrada en vigor de la Constitución Española de 1978 (CE) supuso un profundo proceso de renovación del ordenamiento jurídico para acomodarlo a la nueva configuración de España como Estado social y democrático de Derecho $^{2}$. La incorporación de las libertades públicas al texto constitucional, y, entre ellas, la libertad ideológica como derecho fundamental en condiciones de igualdad para todos los ciudadanos (arts. 14 y 16.1 CE), dio lugar a la quiebra de la profesión de la fe católica como imperativo ético imperante en la sociedad española como consecuencia del modelo de confesionalidad vigente en la historia del constitucionalismo español ${ }^{3}$.

2 J. M. CONTRERAS MAZARío, «El pluralismo religioso y los derechos de las minorías religiosas en España», Bandue, núm. 4 (2010), p. 75.

3 «Es lo que entonces se atinó a denominar nacional-catolicismo: una sociedad enfocada obsesivamente hacia la memoria religiosa de su pasado, un estado confesional que se presentaba 
Como afirman Fernández-Coronado y Suárez Pertierra, «la formulación de estas libertades de convicción supone una novedad ciertamente importante en el ámbito socio-jurídico, pues constituye [...] un empuje definitivo para la secularización de la sociedad» ${ }^{4}$. La irrupción con fuerza de esta libertad entre ciertas elites urbanas modernas y la industrialización de determinadas zonas rurales provoca un tímido y débil proceso de secularización basado en un sentimiento de indiferentismo hacia la Iglesia y la religión católica y, en menor medida, en la práctica en público de aquellas religiones acatólicas ${ }^{5}$ que hasta entonces habían sido perseguidas durante el antiguo régimen. Consciente de este planteamiento, el legislador constitucional también había incorporado el principio del pluralismo como referente axiológico para todo el ordenamiento jurídico ${ }^{6}$, como presupuesto necesario para consolidar un modelo de Estado democrático de Derecho respetuoso con todas las expresiones de religiosidad en el espacio público, siempre que no sean contrarias al propio ordenamiento constitucional ${ }^{7}$. La consolidación de este modelo ha provocado que haya disminuido la intensidad con la que la Iglesia católica venía desempeñando importantes funciones sociales en la esfera pública como la educación ${ }^{8}$, que había monopolizado durante el régimen franquista como instrumento esencial de la formación en los valores propios de la religión católica como mecanismo de control social de la conciencia nacional de la ciudadanía?

Paralelamente, la incorporación en el sustrato constitucional de la igual libertad ideológica de todos los ciudadanos ${ }^{10}$, llevó consigo un nuevo y

como la máxima garantía militar de la unidad católica del país, una esfera pública impregnada de símbolos sacros, unas elites religiosas que jugaban un papel decisivo en el control de la reproducción cultural, un régimen político, en fin, cuyo proyecto originario era mantener a la nación al margen de las fuerzas de la modernidad en lo que se ha denominado "catolización integral de la sociedad" o de "resacralización absoluta de la vida social"». Cfr. M. REQUENA, «Religión y sociedad: la secularización de la sociedad española», en J. J. GonZÁLEZ y M. REQUeNA (eds.), Tres décadas de cambio social en España, 2. ${ }^{a}$ ed., Madrid, Alianza Editorial, 2008, p. 326.

${ }^{4}$ Cfr. A. Fernández Coronado y G. SuÁrez Pertierra, Identidad social, pluralismo religioso y laicidad del Estado, documento de trabajo 2013/180, Madrid, Fundación Alternativas, 2013, p. 24.

5 A. PÉrez-Agote, «El proceso de secularización en la sociedad española», Revista CIDOB d'Afers Internacionals, núm. 77 (2007), p. 69.

6 A. Fernández Coronado y G. SuÁrez Pertierra, Identidad social..., op. cit., p. 27.

7 T. Prieto Álvarez, «Libertad religiosa, pluralismo y espacios públicos», en I. GutiéRREZ y M. A. PRESNO (eds.), La inclusión de los otros: símbolos y espacios de la multiculturalidad, Granada, Comares, 2012, p. 397.

${ }^{8}$ M. REQUENA, «Religión y sociedad...», op. cit., p. 328.

9 A. PÉREZ-Agote, Cambio religioso en España: los avatares de la secularización, Madrid, Centro de Investigaciones Sociológicas, 2012, pp. 144 y ss.

${ }^{10}$ A. M. Vega GutiÉRreZ, «La diversidad religiosa en España: una contextualización 
más profundo proceso de secularización que ha afectado a los jóvenes y adolescentes de nuestros días, que se manifiestan indiferentes hace la fe católica y frente a cualquier forma de religiosidad en general ${ }^{11}$. Se trata de una profunda transformación de la «religiosidad» de los españoles que arraiga especialmente en las nuevas generaciones y que constituye una de las principales dimensiones de los cambios culturales en que se encuentra inmersa la sociedad española en el siglo XXI ${ }^{12}$ : «La progresiva desvinculación de las nuevas generaciones con respecto de las propias raíces de la religión. Este hecho puede repercutir en estas representaciones colectivas culturales presentes hoy en España. En este sentido, parece que la tendencia de futuro puede ir hacia una exculturización, proceso por el cual la cultura va perdiendo las raíces religiosas» ${ }^{13}$. Los jóvenes y adolescentes de nacionalidad española de nuestros días cada vez tienen un menor sentido o conciencia de religiosidad debido al abandono mayoritario de la práctica religiosa por sus padres ${ }^{14}$.

A su vez, la recepción de nacionales de otros países que profesan sus propios credos religiosos ${ }^{15}$ que ha tenido lugar en nuestro país hasta fechas recientes ha favorecido el asentamiento y la consolidación en las estructuras sociales contemporáneas de otras creencias diferentes a la católica. Fenómeno que ha producido como consecuencia la existencia de una notoria diversidad cultural y religiosa en España ${ }^{16}$. El paulatino crecimiento del movimiento migratorio ha provocado profundas transformaciones en la sociedad española contemporánea desde el punto de vista del pluralismo ideológico y cultural ${ }^{17}$, lo que ha generado la necesidad de elaborar por parte de los poderes públicos políticas eficaces de gestión que garanticen la plena libertad para poder disfrutar con plenitud sus ritos, prácti-

sociológica y jurídica», en A. M. VEGA GuTIÉRREZ (coord.), La gestión de la diversidad religiosa en el sistema educativo español, Cizur Menor, Aranzadi-Thomson Reuters, 2014, p. 78.

${ }^{11}$ Como indica Pérez-Agote, «esa traslación se produce desde los católicos practicantes y no practicantes hacia las posiciones, así como, con aún mayor ímpetu, los ateos». Cfr. A. PÉrez-Agote, «El proceso de secularización...», op. cit., pp. 77-78.

${ }_{12}$ M. ReQuenA, «Religión y sociedad...», op. cit., pp. 329 y ss.

${ }^{13}$ Cfr. A. Fernández Coronado y G. SuÁrez Pertierra, Identidad social..., op. cit., p. 36.

${ }^{14}$ Ibid., p. 31.

${ }_{15}$ M. Lega Tome, Laicidad e integración de los inmigrantes, Madrid, Marcial Pons, 2007 , pp. 28 y ss.

16 A. Fernández Coronado y G. Suárez Pertierra, Identidad social..., op. cit., p. 22.

${ }^{17}$ Como advierten Hernando de Larramendi y García Ortiz, el fenómeno migratorio ha dado lugar a un proceso de «recomposición de lo religioso en la modernidad tardía». Vid. «Introducción», en M. HeRnANDO DE LARRAMENDI y P. García ORTIZ (eds.), Minorías religiosas en Castilla-La Mancha, Barcelona, Icaria Editorial-Fundación Pluralismo y Convivencia, 2009, p. 18. 
cas y actividades relacionadas con las convicciones de las personas y de los grupos en que se integran y que conforman este pluralismo ${ }^{18}$. El sentido de estas políticas legislativas opera como criterios que permitan enjuiciar la legitimidad de aquellas prácticas socioculturales que sean diversas a las que forman parte integrante de nuestra identidad nacional ${ }^{19}$.

\section{LA LAICIDAD POSITIVA COMO GARANTÍA INSTITUCIONAL DEL SISTEMA EDUCATIVO PÚBLICO. ALGUNAS CUESTIONES PARTICULARES}

\section{La laicidad positiva como garantía institucional del pluralismo ideológico y religioso}

En este contexto social plural, el factor social ideológico y religioso no puede ser asumido por el Estado a través de fórmulas concretas de adscripción a una creencia determinada, lo que es propio de un país confesional. El Estado neutral requiere la independencia de la religión ${ }^{20}$, de manera que los poderes públicos encargados de tomar decisiones que afecten a todos se encuentren libres, como afirma Habermas, de cualquier tipo de contaminación religiosa ${ }^{21}$. La neutralidad constituye el garante del pluralismo ideológico y del pleno disfrute de la igual libertad ideológica o de conciencia de los ciudadanos en este imaginario social, según la doctrina del Tribunal Constitucional ${ }^{22}$, en tanto en cuanto elemento fundacional de la garantía estacional de la laicidad positiva en el ordenamiento constitucional vigente en España ${ }^{23}$.

A este respecto, la CE no hace referencia expresa al término laicidad. La actitud del Estado español ante el fenómeno social ideológico se encuentra contemplada en el primer inciso del art. 16.3 de la Norma Fundamental,

\footnotetext{
18 R. SÁnCHEZ FerRIZ y C. Elías Méndez, Nuevo reto para la escuela. Libertad religiosa y fenómeno migratorio, Valencia, MINIM, 2002, p. 39.

19 B. AlÁEZ CoRRAL, «Símbolos religiosos y derechos fundamentales en la relación escolar», Revista Española de Derecho Constitucional, núm. 67 (2003), p. 90.

20 A. Fernández Coronado y G. SuÁrez Pertierra, Identidad social..., op. cit., p. 32.

${ }^{21} \mathrm{~J}$. Habermas, «Lo político; el sentido nacional de una cuestionable herencia de la teología política», en VVAA, El poder de la religión en la esfera pública, Madrid, Trotta, 2011, pp. 34-36.

22 SSTC 5/1981, de 13 de febrero, FJ 9. ${ }^{\circ}$, y 177/2015, de 22 de julio, FJ 5. ${ }^{\circ}$

${ }^{23}$ G. SuÁrez Pertierra, «La libertad ideológica, religiosa y de culto. Los principios informadores del Derecho eclesiástico del Estado», en VVAA, Derecho eclesiástico del Estado, 2. ${ }^{\text {e }}$ ed., Valencia, Tirant Lo Blanch, 2016, pp. 126 y ss.
} 
que sólo establece que: «Ninguna confesión tendrá carácter estatal». Para evitar una quiebra absoluta con la ideología nacional del país que, desde la reconquista del Reino del Al-Ándalus, se identificaba con el dogma de la fe católica, el constituyente español se sirvió de esta ambigua terminología para abordar la regulación de la cuestión religiosa, cuya formulación fue fruto de un consenso entre las principales fuerzas políticas y actores sociales de la realidad española de aquel entonces ${ }^{24}$. En efecto, como señala Suárez Pertierra: «La fórmula en cuestión responde a la complejidad de la solución constitucional arbitrada para superar la vieja cuestión religiosa, una fórmula que procede de la necesidad de hallar un sustrato común con el que la mayoría de los ciudadanos pueda identificarse y que se elabora como respuesta constructiva a las presiones sociales que se producen en el contexto constitucional desde los servicios más conservadores» ${ }^{25}$. Esta terminología responde, en suma, a la necesidad de obtener el apoyo institucional de la jerarquía eclesiástica al refrendo del texto constitucional por parte de los ciudadanos que, hasta entonces, profesaban mayoritariamente la religión católica ${ }^{26}$. Pero, ¿qué quiere decir que «ninguna confesión tendrá carácter estatal»?

Ante la ambigüedad de esta expresión, algunos autores han entendido que el art. 16.3 de la Constitución ha instaurado un modelo de «no confesionalidad» fundado en una valoración positiva e institucional del fenómeno religioso ${ }^{27}$, mientras que otro sector doctrinal considera que aquel pre-

${ }^{24}$ J. Martínez Torrón, Separatismo y cooperación en los acuerdos del Estado con las minorías religiosas, Granada, Comares, 1994, p. 20.

${ }^{25}$ Cfr. G. SuÁrez Pertierra, «La laicidad en la Constitución española», en J. Martínez TORRón (ed.), Estado y religión en la Constitución Española y en la Constitución Europea, Granada, Comares, 2005, p. 17.

${ }^{26} \mathrm{Y}$ es que, en el fondo, como afirma Lema Tomé, la regulación de la cuestión religiosa en la Constitución Española de 1978 es fruto del conjunto de valores éticos que conformaban el sentido del patriotismo constitucional o ideología nacional de la sociedad española de aquel entonces. Vid. L. Tomé, Laicidad e integración de los inmigrantes, Madrid, Marcial Pons, 2007, p. 204.

${ }^{27}$ Entre otros vid. E. Molano, «La laicidad del Estado en la Constitución Española», ADEE, núm. 2 (1986), pp. 239-256; F. FERRER OrTIZ, «Laicidad del Estado y cooperación con las confesiones», ADEE, núm. 3 (1987), pp. 237-248; J. Martí SÁnCHEZ, «El concepto de laicidad y su evolución en el Derecho francés», Revista Española de Derecho Canónico, núm. 50 (1993), pp. 251-278; R. NAVARro Valls, «Los Estados frente a la Iglesia», ADEE, núm. 9 (1993), pp. 17-51; íD., «El principio de cooperación y la laicidad del Estado», en J. MARTínez Torrón (ed.), Estado y religión en la Constitución Española y en la Constitución Europea, Granada, Comares, 2005, pp. 31-42; M. J. RocA, «La neutralidad del Estado: fundamento doctrinal y actual delimitación en la jurisprudencia», Revista Española de Derecho Constitucional, núm. 16 (1996), pp. 251-272; J. MARTínez TORRón, Separatismo..., op. cit.; íD., Religión, derecho y sociedad, Granada, Comares, 1999; J. Calvo Álvarez, Los principios 
cepto ha consagrado implícitamente un sistema de laicidad ${ }^{28}$. Y es que, en realidad, como afirma Fernández-Coronado, un Estado «aconfesional» no

del Derecho eclesiástico español en las sentencias del TC, Pamplona, Universidad Privada de Navarra, 1998; J. M. GonZÁlez del VAlLe, Derecho eclesiástico español, Oviedo, Universidad de Oviedo, 1997; I. C. Iban, Manual de Derecho eclesiástico, Madrid, Trotta, 2004, y J. Amorós, La libertad religiosa en la Constitución española de 1978, Madrid, Tecnos, 1984.

${ }^{28}$ Entre otros vid. D. LlamaZARES FernánDEZ, «Actitud de la España democrática ante la Iglesia», en I. C. IBAN (coord.), Iglesia católica y regimenes autoritarios y democráticos (experiencia española e italiana), Madrid, EDERSA, 1987, pp. 159-194; ÍD., «El principio de cooperación del Estado con las confesiones religiosas. Fundamentos, alcance y límites», ADDE, núm. 5 (1989), pp. 69-101; íD., «Principios, técnicas y modelos de relación entre Estado y grupos ideológicos», Revista de Estudios Políticos, núm. 88 (1995), pp. 29-61; íD., «Derecho de la libertad de conciencia: la construcción del sistema», Laicidad y libertades. Escritos jurídicos, núm. 1 (2001), pp. 271-303; íD., «Laicidad, libertad de conciencia y acuerdos del Estado con las confesiones religiosas», en D. LlamaZARes FernándeZ (dir.), Libertad de conciencia y laicidad en las instituciones y servicios públicos, Madrid, Dykinson, 2005, pp. 7-32; ÍD., Derecho de la libertad de conciencia, t. I, Madrid, Civitas, 1997; A. Fernández CoronaDO, «Principio de igualdad y técnica de cooperación», La Ley, núm. 2 (1983), pp. 76-83; íD., Estado y confesiones religiosas: un nuevo modelo de relación. Los pactos con las confesiones: Leyes 24, 25 y 26 de 1992, Madrid, Civitas, 1995; íD., «Evolución y desarrollo de la cooperación confesional en el sistema español. Balance y propuesta de futuro», Laicidad y libertades. Escritos jurídicos, núm. 3 (2003), pp. 135-156; íD., «El significado del art. 16 en el contexto constitucional», en A. FERnÁNDEZ Coronado et al. (coords.), Libertad de conciencia, laicidad y Derecho, Madrid, Civitas-Thomson Reuters, 2014, pp. 87-106; A. Fernández Coronado y G. SuÁrez Pertierra, Identidad social, pluralismo religioso y laicidad del Estado, Madrid, Fundación Alternativas, 2013; G. SuÁrez PerTiERRA, «La recuperación del modelo constitucional. La cuestión religiosa a los veinticinco años de vigencia de la Constitución», Laicidad y libertades. Escritos jurídicos, núm. 2 (2002), pp. 313-348; íD., «Individuo, grupos, confesiones, en el sistema democrático español», en F. AmÉRIGo (ed.), Religión, religiones, identidad, identidades. Minorías. Actas del V Simposio de la Sociedad Española de Ciencias de las Religiones, Valencia, Sociedad Española de Ciencias de las Religiones, 2002, pp. 7-24; G. SUÁrEZ PERTIERRA, «La laicidad en la Constitución...», op. cit.; ÍD., «La cuestión religiosa: vigencia de los veinticinco años de la Constitución», Cuadernos Constitucionales de la Cátedra Fadrique Furiol Ceriol, núm. 40 (2002), pp. 45-55; J. M. Contreras MazArío, «Principio de laicidad y asistencia religiosa en centros universitarios público», Derechos y Libertades, núm. 8 (2000), pp. 99-160; íD., «La libertad de conciencia...», op. cit.; M. C. LlamaZARES CALZADILLA, «Derecho eclesiástico del Estado: la formación de un sistema», Laicidad y libertades. Escritos jurídicos, núm. 2 (2002), pp. 237-276; J. A. Souto Paz y C. Souto Galván, El derecho de la libertad de creencias, Madrid, Marcial Pons, 2011; J. A. Souto PAZ, «Libertad religiosa y de creencias», en J. MARTínez TORRóN (ed.), Estado y religión en la Constitución Española y en la Constitución Europea, Granada, Comares, 2005, pp. 1-10; A. CASTRO Jover, «Laicidad y actividad positiva de los poderes públicos», Revista General de Derecho Canónico y Derecho Eclesiástico del Estado, núm. 3 (2003), pp. 1-25; A. ToRres GuTIÉRREZ, «La levedad de la laicidad y sus claroscuros en España», en A. FeRnÁndEZ CoRONADO et al. (coords.), Libertad de conciencia, laicidad y Derecho, Madrid, Civitas-Thomson Reuters, 2014, pp. 133 158; J. R. Polo SABaU, ¿Derecho eclesiástico del Estado o libertades públicas? Notas para una interpretación sistemática del art. 16 de la Constitución, Málaga, Servicio de Publicaciones de la Universidad de Málaga, 2002; Y. García Ruiz, «¿Qué laicidad queremos?», en A. FerNÁNDEZ Coronado et al. (coord.), Libertad de conciencia, laicidad y Derecho, Madrid, CivitasThomson Reuters, 2014, pp. 108-132; S. Pérez ÁlvareZ, «Espejismos del pasado en el régi- 
puede ni debe entenderse como una categoría intermedia entre la confesionalidad predominante en el constitucionalismo histórico español y un sistema de laicidad, sea o no positiva ${ }^{29}$. Los términos «aconfesionalidad» $\mathrm{y}$ «laicidad positiva» hacen referencia a un único modelo de gestión del factor social ideológico y/o religioso ${ }^{30}$, el instaurado por la CE de 1978. Frente al resto de sistemas de laicidad vigentes en nuestro entorno más cercano ${ }^{31}$, el constituyente español ha incorporado como elemento integrante de dicho sistema el mandato impuesto a los poderes públicos en el segundo inciso del art. 16.3 de «tener en cuenta las creencias religiosas de la sociedad española y mantendrán las consiguientes relaciones de cooperación con la Iglesia católica y las demás confesiones « ${ }^{32}$. Siguiendo a Suárez Pertierra, la cooperación con las comunidades religiosas e ideológicas es el tercer elemento que caracteriza a la actitud que deben mantener los poderes públicos ante el fenómeno social ideológico y religioso ${ }^{33}$. Así se deduce de la doctrina del Tribunal Constitucional (TC) en esta materia, que hace hincapié en el tercer elemento del modelo de laicidad propio del ordenamiento jurídico español, que al principio era calificado con el término de aconfesionalidad ${ }^{34}$ y que, desde su Sentencia 46/2001, de 15 de febrero, viene empleando dicha expresión como sinónima de la nomenclatura más moderna de «laicidad positiva» ${ }^{35}$.

men jurídico de la enseñanza religiosa judía en las España de hoy», en I. MARTín SÁNCHEz y M. GonZÁlez SÁnCHeZ (coords.), Cuestiones del Acuerdo entre el Estado y la FCJE, Madrid, Delta Publicaciones, 2010, pp. 197-231, e íD., «Reflejos del pasado en la gestión de la realidad islámica española contemporánea», E-Legal History Review, núm. 9 (2010), pp. 1-31.

29 A. Fernández Coronado, «El significado del art. 16 en el contexto constitucional...», op. cit., p. 98.

${ }^{30}$ En este sentido coincidimos, no sin matices, con la consideración de Palomino de que «otra forma de aproximación a la laicidad es entenderla como equivalente a la aconfesionalidad, en el sentido de designar que el Estado no tiene una religión oficial a la que protege». Cfr. R. PAlomino Lozano, «Laicidad, laicismo, ética pública; presupuestos en la elaboración de políticas para prevenir la radicalización violenta», Athena Intelligence Journal, núm. 3 (2008), p. 89.

31 Sobre un análisis de los modelos de laicidad vigentes en la UE vid. A. FernándeZ CORONADO, «El derecho de la libertad de conciencia en los países miembros de la UE (II)», en A. Fernández Coronado (dir.), El derecho de la libertad de conciencia en el marco de la UE: pluralismo y minorías, Madrid, Colex, 2002, pp. 83-93, y A. RodríGuez MoYA, «Sistemas de relación Iglesia-Estado en Europa. El Derecho de la Unión Europea», en G. SuÁREZ Pertierra et al., Derecho eclesiástico del Estado, Valencia, Tirant Lo Blanch, 2013, pp. 77-86.

32 A. Fernández Coronado y G. SuÁrez Pertierra, Identidad social..., op. cit., p. 68.

33 G. SuÁrez Pertierra, «La laicidad en la Constitución...», op. cit., p. 29.

34 SSTC 1/1981, de 26 de enero; 62/1982, de 15 de octubre; 66/1982, de 12 de noviembre; 616/1984, de 31 de octubre; 617/1984, de 31 de octubre; 19/1985, de 13 de febrero; $359 / 1985$, de 29 de mayo; 180/1986, de 21 de febrero; 130/1991, de 6 de junio; 340/1993, de 16 de noviembre; 177/1996, de 11 de noviembre, y 6/1997, de 13 de enero.

${ }_{35}$ Desde su Sentencia 46/2001, de 15 de febrero, el TC utiliza indistintamente los tér- 
El sentido de esta actitud colaboracionista del Estado no debe ser interpretado de manera estática ${ }^{36}$, pues, de lo contrario, la compleja fórmula empleada por la Constitución para regular el fenómeno ideológico en España no podría adecuarse a las exigencias de la sociedad española contemporánea ${ }^{37}$. El profundo arraigo social de la religión católica en la ideología nacional de aquel entonces y los temores ante las repercusiones que pudieran derivarse del rechazo por parte de la jerarquía eclesiástica de una ruptura radical con el modelo de confesionalidad aún vigente determinaron que, en sus inicios, la aconfesionalidad estatal hundiera sus raíces en el mantenimiento por parte de los poderes públicos de relaciones de cooperación institucional con esta confesión religiosa. La realización efectiva del mandato constitucional de cooperación se plasmó en la firma de cuatro acuerdos sectoriales con la Santa Sede el 3 de enero de $1979^{38}$ que, en su conjunto, formaban un complejo concordatario ${ }^{39}$, tal y como se deduce de las primeras sentencias del TC en esta materia ${ }^{40}$.

La paulatina evolución de esta idea de cooperación institucional con las comunidades ideológicas se debió a otro fenómeno sociológico que nace como consecuencia del reconocimiento, en condiciones de igualdad real y efectiva, del derecho fundamental a la libertad ideológica: el fenómeno de secularización de la conciencia nacional española ${ }^{41}$. En efecto, la consagración de esta libertad en el art. 16.1 CE trajo consigo un profundo cambio en las creencias de los ciudadanos que, poco a poco, dejaron de identificarse única y exclusivamente con la fe católica ${ }^{42}$, abriendo paso a un nuevo

minos de «aconfesionalidad» o «laicidad positiva» excepto en su fallo 51/2011, de 14 de abril, que sólo utiliza el término de aconfesionalidad para referirse a la actitud que deben mantener los poderes públicos ante el fenómeno social ideológico y religioso. A este respecto vid. SSTC 46/2001, de 15 de febrero; 154/2002, de 18 de julio; 101/2004, de 2 de junio; 38/2007, de 15 de febrero; 28/2007, de 4 de junio; 34/2011, de 28 de marzo, y 207/2013, de 5 de diciembre.

36 A. Fernández Coronado, «Sentido de la cooperación del Estado laico en una sociedad multireligiosa», Revista General de Derecho Canónico y Derecho Eclesiástico del Estado, núm. 19 (2009), p. 2.

${ }^{37}$ J. MARTínez TORRÓn, Religión, derecho..., op. cit., p. 214.

38 Sobre los instrumentos de ratificación de los acuerdos concertados entre el Estado español y la Santa Sede de 3 de enero de 1979 vid. BOE, núm. 300, de 15 de diciembre de 1979.

39 D. Llamazares FernÁNDEZ, «Laicidad, libertad de conciencia...», op. cit., p. 18.

40 SSTC 1/1981, de 26 de enero; 62/1982, de 15 de octubre; 66/1982, de 12 de noviembre; 616/1984, de 31 de octubre; 617/1984, de 31 de octubre; 19/1985, de 13 de febrero; 359/1985, de 29 de mayo; 180/1986, de 21 de febrero; 130/1991, de 6 de junio; 340/1993, de 16 de noviembre; 177/1996, de 11 de noviembre, y 6/1997, de 13 de enero.

41 A. Fernández Coronado y G. SuÁrez Pertierra, Identidad social..., op. cit., pp. 22-29.

42 J. Martínez TORRón, Religión, derecho..., op. cit., pp. 214-215. 
pluralismo religioso y cultural como característica propia de la sociedad española contemporánea. Los valores que conforman esta diversidad forman parte integrante de la cultura jurídica que ha evocado reiteradamente el TC para contextualizar el ordenamiento jurídico «como un fenómeno social vinculado a la realidad en que se desarrolla» ${ }^{43}$ y que, por ello precisamente constituye la pieza fundamental para entender la interpretación evolutiva del significado constitucional del mandato de cooperación que singulariza al modelo de laicidad positiva vigente en España.

La adaptación del modelo a esta realidad social es el factor determinante de la interpretación evolutiva del art. 16.3 CE que viene realizando el TC, que desde 2001 concibe actualmente el mandato de cooperación como un mecanismo promocional de la libertad ideológica de los ciudadanos y de los grupos en que se integran ${ }^{44}$, esto es, la esencia del sistema se basa en garantizar, y, en su caso, remover, todos los obstáculos que dificulten el pleno disfrute de las dimensiones individual y colectiva de este derecho fundamental ${ }^{45}$. Así entendido, y como ya hemos defendido con anterioridad $^{46}$, el principio de aconfesionalidad o de laicidad positiva es una de las garantías institucionales del orden constitucional contemporáneo. Esta noción hace referencia a institutos jurídicos y a principios constitucionalmente protegidos ${ }^{47}$ que constituyen «elementos arquitecturales indispensables del orden constitucional, y las normaciones que las protegen son, sin duda, normaciones organizativas, pero, a diferencia de lo que sucede con las instituciones supremas del Estado, cuya regulación orgánica se hace en el propio texto constitucional [...] no han sido más que enunciadas en la Constitución, sin encontrar en ella el imprescindible desarrollo del orden constitucional vigente» ${ }^{48}$.

La laicidad positiva como garantía institucional posee una doble vertiente: una objetiva y otra subjetiva. La vertiente objetiva se identifica con el compromiso asumido por el Estado en esta materia por imperativo del primer

${ }^{43}$ STC 198/2012, de 6 de noviembre, FJ 9. ${ }^{\circ}$ En sentido similar vid. SSTC 17/1985, de 9 de febrero, FJ 4..$^{\circ}$; 89/1993, de 12 de marzo, FJ 3. ${ }^{\circ}$; 341/1993, de 18 de noviembre, FJ 3. ${ }^{\circ}$; 29/1995, de 6 de febrero, FJ 3. ${ }^{\circ} ; 298 / 2000$, de 11 de diciembre, FJ $1{ }^{\circ}$, y 198/2012, de 6 de noviembre, FJ 9.

${ }^{44}$ SSTC 46/2001, de 15 de febrero; 154/2002, de 18 de julio; 101/2004, de 2 de junio; $38 / 2007$, de 15 de febrero; 28/2007, de 4 de junio; 34/2011, de 28 de marzo, y 207/2013, de 5 de diciembre;

45 A. FERnÁNDEZ CoRonado, «Sentido de la cooperación...», op. cit., pp. 4-7.

46 S. PÉREZ ÁlLVAREZ, «La laicidad positiva como garantía institucional del sistema matrimonial español», Laicidad y libertades. Escritos Jurídicos, núm. 15, fasc. 1 (2016), pp. 248-254.

47 STC 19/1985, de 13 de febrero, FJ $1 .^{\circ}$

48 SSTC 32/1981, de 28 de julio, FJ 3. ${ }^{\circ}$, y 198/2012, de 6 de noviembre, FJ 9. 
inciso del art. $16.3 \mathrm{CE}^{49}$, esto es: 1) la separación entre el Estado y las comunidades ideológicas que veta cualquier tipo de confusión por parte de los poderes públicos entre los fines estatales y los ideológicos o religiosos, y 2) la neutralidad ante el fenómeno social ideológico y religioso como garante de la igual libertad ideológica o de conciencia de los ciudadanos en un contexto social plural ${ }^{50}$. Por su parte, la vertiente subjetiva es la relativa a la actitud que deben mantener los poderes públicos ante los derechos y las libertades individuales en juego ${ }^{51}$, y consiste en el mandato de cooperar con las comunidades ideológicas y religiosas hasta donde sea necesario para garantizar y, en su caso, promover la igual libertad ideológica o de conciencia de los ciudadanos ${ }^{52}$. La consecución de este objeto debe llevarse a cabo dentro de los límites que imponen el debido respeto a la vertiente objetiva de esta garantía institucional ${ }^{53}$, es decir, la neutralidad y la separación como elementos funcionales de esta garantía institucional en todos y cada uno de los ámbitos de la esfera pública donde se proyectan las convicciones de los ciudadanos ${ }^{54}$.

\section{La laicidad positiva como garante de la libertad para formar en y para la libertad la propia ideología o conciencia en el sistema educativo público}

Uno de los ámbitos donde confluyen los intereses del Estado y de las comunidades religiosas con arraigo social en nuestro país es el educati-

49 A. Ruiz Miguel, «Libertad religiosa, símbolos religiosos y laicidad estatal», en I. GutiérReZ GutiérRez y M. A. PRESNo (eds.), La inclusión de los otros: símbolos y espacios de la multiculturalidad, Granada, Comares, 2012, p. 80.

${ }_{50}$ G. SuÁrez PertiERRA, «La libertad ideológica, religiosa y de culto...», op. cit., pp. 126 y ss.

51 A. Ruiz Miguel, «Libertad religiosa, símbolos religiosos...», op. cit., p. 80.

52 Notas que permiten configurar a este principio como garantía institucional del ordenamiento constitucional y que constituyen, además, lo que la doctrina ha considerado como «las nuevas fronteras de la laicidad» en nuestros días. Sobre un análisis en profundidad de todos ellos vid. A. Fernández Coronado y G. Suárez Pertierra, Identidad social..., op. cit., pp. 59-77.

53 Sobre los límites que impone al legislador el debido respeto a las garantías institucionales del ordenamiento constitucional vigente vid. SSTC 32/1981, de 28 de julio, FJ 3.'; 26/1987, de 27 de febrero, FJ 4.a); 76/1988, de 26 de abril, FJ 4. ${ }^{\circ} ; 109 / 1998$, de 21 de mayo, FJ 2. ${ }^{\circ}$; 159/2001, de 5 de julio, FJ $4 .^{\circ}$, y 101/2013, de 23 de abril, FJ 11.

${ }^{54} \mathrm{Y}$ en el bien entendido, insistió, de que hablo de proyecciones de unas determinadas convicciones al espacio publico, no de que dichos sistemas de creencias o identidades religiosas se identifiquen o formen parte de dicho espacio público laico, pues por ser precisamente laico no puede identificarse ni tener ningún tipo de identidad religiosa. Vid. F. SANTAMARÍA LAMBÁS, «La cuestión religiosa en el espacio público: cuestiones jurídicas sobre los símbolos religioso estáticos», en J. TORRES y S. ACERBI (eds.), La religión como factor de identidad, Madrid, Escolar y Mayo, 2016, pp. 190 y ss. 
$v^{55}$. El modelo vigente en España es heredero directo del pensamiento ilustrado en que se inspiró el Informe Quintana de 9 de septiembre de 1813 que contiene las líneas maestras del mismo tal y como lo conocemos en nuestros días ${ }^{56}$. El modelo educativo propuesto respondía tanto a la concepción de Talleyrand de la educación pública como «el arte de poner a los hombres en todo su valor, tanto para ellos como para sus semejantes» ${ }^{57}$, como a los postulados defendidos por Condorcet de que era condición necesaria para que tenga lugar la maduración de la personalidad de los hombres en régimen de libertad ${ }^{58}$ y que, por tanto, debía ser igual, completa y universal para todos los ciudadanos ${ }^{59}$. En concreto, este poeta ilustrado postulaba que «mientras más dispuestos estén los hombres, por la educación, a razonar con justeza, a apoderarse de las verdades que se les presentan y a rechazar los errores de los que se les quiere hacer víctimas, más también puede esperar, obtener y conservar buenas leyes una administración sabia y una constitución verdaderamente libre la nación que vea acrecentarse así las luces cada vez más y repartirse sobre un mayor número de individuos» ${ }^{60}$. Según este pensamiento ilustrado, la educación pública persigue como finalidad primordial que las personas «razonen con justeza, apoderarse de las verdades que se les presentan y rechazar los errores de los que se les quiere hacer víctimas». Me refiero al «conjunto de ideas fundamentales que caracteriza el pensamiento de una persona, colectividad o época, de un movimiento cultural, religioso o político, etc.» o la propia ideología tal y como es definida por el Diccionario de la Real Academia.

55 A. García SAntesmases, «La religión en el espacio público», Laicidad y libertades. Escritos jurídicos, núm. 14, fasc. 1 (2014), pp, 228 y ss.

56 D. Llamazares Fernández, Derecho de la libertad de conciencia. Conciencia, identidad personal y solidaridad, t. II, 4. a ed., Pamplona, Civitas-Thomson Reuters, 2011, p. 62.

${ }_{57}$ Cfr. C. Hippeau, L'instruction publique en France pendant la Révolution: L'Instruction publique en France pendant la Révolution: discours et rapports de Mirabeau, Talleyrand-Périgord, Condorcet, Lanthenas, Romme, Le Peletier de Saint-Fargeau, Paris, Didier et Cie Libraires-Editeurs, 1881, p. 113.

${ }^{58}$ R. MORÁN MARTín, «El derecho a la educación en el constitucionalismo español del siglo XIX y su concepción en la obra de Concepción Arenal», Boletín de la Facultad de Derecho de la UNED, núm. 10-11 (1996), pp. 53 y ss.

${ }^{59}$ Los planteamientos de Quintana de que la instrucción pública debe ser igual, completa y universal para todos están basados en los planteamientos de Condorcet: «Nous avons pensé que, dans ce plan d'organisation générale, notre premier soin devait étre de rendre, d'un côté, l'education aussi égale, aussi universelle; de l'autre, aussi complète que les circonstances pouvaient le permettre». Sobre este fragmento del pensamiento de Condorcet cfr. B. BACZKO, Une éducation pour la démocratie. Textes et projets de l'époque révolutionnaire, Paris, Garnier, 1982, p. 182.

${ }^{60}$ Cfr. N. DE Condorcet. Escritos pedagógicos, Madrid, Espasa-Calpe, 1922, p. 18. 
Ahora bien, ello no implica que cualquier acto del entendimiento o pensamiento humano ${ }^{61}$ contribuya de manera decisiva a la maduración de la personalidad de los hombres, sino tan sólo aquellas ideas en que se fundamenta el raciocinio humano ${ }^{62}$ y que, como advierte Ortega y Gasset, «constituyen el continente de nuestra vida y, por ello, no tienen el carácter de contenidos particulares dentro de ésta» ${ }^{63}$. El conjunto de ideas que forman parte de la esencia de la realidad personal de cada sujeto son definidas por el citado autor como «creencias» ${ }^{64}$, que se diferencian de las «simples ideas» en que, como señala Llamazares Fernández, no son consustanciales a la propia esencia del ser humano, ya que pueden ser sometidas a juicios de contrastabilidad por parte de quien las posee ${ }^{65}$. Desde el punto de vista de la psicología social, la expresión «ideología» es comprensiva de aquel sistema de creencias constitutivas de la esencia de la psique de cada persona en sí considerada que dirigen y modulan las pautas de su comportamiento en relación con el mundo que le rodea ${ }^{66}$.

Así entendidas, se puede afirmar con Ortega y Gasset que las creencias «se confunden para nosotros con la realidad misma», son «nuestro mundo y nuestro ser» ${ }^{67}$, y constituyen lo que Llamazares Fernández califica como auténticas «convicciones» ${ }^{68}$. Consecuentemente, el objeto mediato de la ideología de una persona en una época y en un contexto social dado son las creencias o convicciones ${ }^{69}$. Las creencias se caracterizan por la nota de su firmeza, lo que implica que son percibidas por el sujeto que las profesa como un elemento perteneciente a su propia identidad personal a través de su conciencia ${ }^{70}$, y cualquier incongruencia con ellas es por él considerada como una tracción a sí mismo ${ }^{71}$. El término «conciencia» es definido por el

${ }^{61}$ Éste es el significado actual del término «ideas» frente a su sentido originario o «visión» que procedía de la traducción literal del término griego «eidos». Vid. S. TARODO SORIA, Libertad de conciencia y derechos del usuario de los servicios sanitarios, San Sebastián, Servicio de Publicaciones de la Universidad del País Vasco, 2004, pp. 65-66.

${ }_{62}$ Ésta es la primera acepción que atribuye el Diccionario de la Real Academia Española a la palabra «fundamento» que procede del término latín «fundamentum».

${ }_{63}$ Cfr. J. Ortega y Gasset, Ideas y creencias, 2. ${ }^{a}$ reimp., Madrid, Alianza, 1995, p. 24.

${ }^{64}$ Ibid.

${ }^{65}$ D. Llamazares Fernández, Derecho de la libertad..., op. cit., t. I, pp. 17 y ss.

${ }^{66}$ M. Herrera y J. Seone, «Actitudes e ideología política», en A. Rodríguez y J. Seone (coords.), Creencias, actitudes y valores, Madrid, Alhambra, 1989, pp. 420-421.

${ }^{67}$ Cfr. J. Ortega y Gasset, Ideas..., op. cit., p. 24.

${ }^{68}$ D. Llamazares Fernández, Derecho de la libertad..., op. cit., t. I, p. 20.

${ }^{69}$ D. McLlean, Ideology, Milton Keynes, Open University Press, 1986, p. 1.

70 D. Llamazares Fernández, Derecho de la libertad..., op. cit., t. I, pp. 17 y ss.

${ }^{71}$ M. C. Llamazares Calzadilla, Las libertades de expresión e información como garantía institucional, Madrid, Thomson Reuters-Civitas, 1999, p. 59. 
Diccionario de la Real Academia Española, entre otras acepciones, como «la propiedad del espíritu humano de reconocerse en sus atributos esenciales y en todas las modificaciones que en sí mismo experimenta». A su vez, estos atributos esenciales no son otros que el conjunto de ideas fundamentales o convicciones que constituyen su propia ideología ${ }^{72}$. En consecuencia, la «ideología» y la «conciencia» de una persona se proyectan sobre el mismo sistema de ideas, creencias y/o convicciones, de ahí que, desde el punto de vista de su objeto formal en definitiva, son dos términos sinóni$\operatorname{mos}^{73}$. Pues bien, ya desde principios del siglo XIX, la educación perseguía como finalidad promover la libre formación de la ideológica o conciencia del discente. $\mathrm{Y}$ es que, en el fondo, como viene defendiendo Llamazares Fernández desde hace años, el derecho a la educación no es otra cosa que «el derecho a formar en libertad y para la libertad la propia conciencia» ${ }^{74}$. Definición que ha sido ratificada por la doctrina del Tribunal Europeo de Derechos Humanos (TEDH) que la define como «el procedimiento total mediante el cual en cualquier sociedad los adultos inculcan a los más jóvenes sus creencias, hábitos y demás valores» ${ }^{75}$ con la finalidad primordial de promover «el desarrollo y la formación del carácter y el espíritu de los alumnos, así como su autonomía personal» ${ }^{76}$.

Así entendida, la educación está íntimamente relacionada con la transmisión de contenidos, competencias y valores, y su objetivo primordial consiste en el desarrollo del alumnado y su preparación para su integración en el entorno social que le rodea ${ }^{77}$. Nos hallamos ante la piedra angular del progreso de los pueblos ${ }^{78}$, la variable estratégica de mayor trans-

72 J. A. XIOL Rios, «La libertad ideológica o la libertad de conciencia», en VVAA, $L a$ libertad ideológica. Actas de las VI Jornadas de la Avocación de Letrados del Tribunal Constitucional, Madrid, CEPC, 2001, pp. 16 y ss.

73 M. C. Llamazares Calzadilla, «Libertad de conciencia y dignidad humana», en VVAA, Estudios en homenaje al profesor Martínez Valls, vol. I, Alicante, Servicio de Publicaciones de la Universidad de Alicante, 2000, pp. 348 y 349.

${ }^{74}$ D. Llamazares Fernández, Derecho de la libertad..., op. cit., t. II, p. 57.

75 Asuntos núms. 7511/1976 y 7743/1976, Campbell y Cosans contra Reino Unido, de 25 de febrero de 1982, núm. 33.

${ }_{76}$ Asunto núm. 1448/04, Hasan y Eylem Zengin contra Turquía, de 9 de octubre de 2007, núm. 55.

77 A. Leturia NavaroA, «Educación para la inclusión en un modelo intercultural de gestión de la diversidad», en A. CASTRO Jover (dir.), Interculturalidad y Derecho, Pamplona, Aranzadi-Thomson Reuters, 2013, p. 89.

${ }^{78}$ De ahí la eterna pretensión de los Estados totalitaristas o de los regímenes constitucionales ideológicamente monistas como, por ejemplo, el sistema de confesionalidad católica predominante en la historia del constitucionalismo español de implantar un sistema educativo basado en los valores y en los imperativos categóricos propios de la ideología predomi- 
cendencia para abordar los retos del presente, para desarrollar el capital humano, para impulsar el desarrollo y el cauce instrumental para la conformación de la identidad personal del ser humano conforme a la propia conciencia $^{79}$. Más en un contexto ideológica y culturalmente plural como es la sociedad española de nuestros días, en donde «la actividad del Estado en materia de educación [...] no solo debe asegurar la transmisión del conocimiento del entramado institucional del Estado, sino también ofrecer una instrucción o información sobre valores necesarios para el buen funcionamiento del sistema democrático» ${ }^{80}$.

La acción educativa pública debe potenciar tanto las capacidades cognitivas de los ciudadanos para vivir libre y responsablemente como sus facultades intelectivas para poder analizar, discernir y saber cómo actuar ante cada situación que deban afrontar a lo largo de su devenir vital presente y futuro ${ }^{81}$. Hipótesis que hunde sus raíces en la doctrina del TC contenida en la Sentencia 133/2010, donde se afirma que el sistema educativo español persigue como fin esencial «el libre desarrollo de la personalidad individual en el marco de una sociedad democrática y [...] la formación de ciudadanos respetuosos con los principios democráticos de convivencia y con los derechos y libertades fundamentales» ${ }^{82}$. La consecución de ambos fines constituye el «ideario educativo de la Constitución» ${ }^{83}$, cuya finalidad principal consiste en que la acción educativa sea el mecanismo a través del cual el discente sea capaz de alcanzar su plena autodeterminación en todas las facetas de su vida ${ }^{84}$. Los frutos de dicha acción proporcionará a los alumnos «el bagaje cultural necesario para su legítimo y pleno ejercicio de la libertad ideológica, comprensiva de todas las opciones que suscita la vida personal y social, entre las que se incluyen las convicciones

nante, ya sea de base religiosa o no. Sobre un análisis en profundidad de esta materia vid. M. A. Asensio SÁnchez, «Análisis histórico-jurídico del art. 27 de la Constitución española de 1978: un camino para entender nuestro sistema educativo», en J. R. Polo SABAU (dir.), Anuario del Derecho a la Educación II, Madrid, Dykinson, 2012, pp. 13-22.

${ }_{79}$ G. SuÁrez Pertierra, «Educación en valores y multiculturalidad», en G. SuÁrez PerTIERRA y J. M. CONTRERAS MAZARIo (coords.), Interculturalidad y educación en Europa, Valencia, Tirant Lo Blanch, 2005, p. 437.

${ }^{80} \mathrm{Cfr}$. A. EmbID IRUjo, «Educar a ciudadanos. Reflexiones en torno a las Sentencias del Tribunal Supremo de 11 de febrero de 2009 sobre la "Educación para la ciudadanía"», El Cronista, núm. 4 (2009), pp. 43 y ss.

81 G. SuÁrez PertierRA, «Educación en valores...», op. cit., p. 437.

82 STC 133/2010, de 2 de diciembre, FJ 8.B).

${ }^{83}$ STC 5/1981, de 13 de febrero, FJ 8. ${ }^{\circ}$, y ATC 40/1999, de 20 de febrero, FJ 2. ${ }^{\circ}$

${ }^{84}$ P. Nuevo LóPez, «Derechos fundamentales e ideario educativo constitucional», Revisa de Derecho Político, núm. 89 (2014), pp. 209 y ss. 
que se tengan respecto del fenómeno religioso y del destino último del ser humano ${ }^{85}[\ldots]$ Y que está reconocida en el art. 16.1 CE por ser fundamento, justamente con la dignidad de la persona y los derechos inviolables que le son inherentes, según se proclama en el art. 10.1 CE, de otras libertades y de derechos fundamentales» ${ }^{86}$. «Dicho de otro modo: se persigue educar en la tolerancia y en el respeto a las convicciones ajenas, valores sin los cuales no hay una sociedad democrática ${ }^{87}$ y para cuya efectiva realización es precisa la maduración intelectual en una mentalidad amplia y abierta» ${ }^{88}$.

El derecho de todos los alumnos a formar en y para la libertad la propia ideología o conciencia constituye, por tanto, la piedra angular del ideario educativo constitucional ${ }^{89}$ y debe ser garantizado y, en su caso, promocionado por parte de las autoridades educativas en condiciones de igualdad reales y efectivas. Sobre todo en contextos tan plurales desde los puntos de vista ideológico y cultural como los que caracterizan a los que se encuentran matriculados en este tipo de instituciones ${ }^{90}$. Y es aquí donde entra en juego la garantía institucional de la laicidad positiva como uno de los elementos que forman parte de dicho ideario, pues, como dijimos, la finalidad esencial que persigue la vertiente subjetiva de la misma es garantizar, y, en su caso, promover, la igual libertad ideológica de todos los ciudadanos en un contexto plural. Ahora bien, como ya señaló hace años Suárez Pertierra, este ideario constitucional laico no concierne únicamente a los aspectos espirituales del tipo de enseñanzas impartidas en el centro docente de que se trate, sino que impregna toda la actividad que tiene lugar en el interior del mismo ${ }^{91}$. De ahí que el respeto al mismo implique que tanto la acción educativa como la ordenación de las infraestructuras y/o dependencias de los centros docentes públicos, deben ser

${ }^{85}$ STC 292/1993, de 18 de octubre, FJ 5. ${ }^{\circ}$

${ }^{86}$ STC 20/1990, de 27 de junio, FJ 4. ${ }^{\circ}$, y ATC 40/1999, de 22 de febrero, FJ $2 .^{\circ}$

${ }^{87}$ SSTC 6271982, de 15 de octubre, FJ 5. ${ }^{\circ}$; 107/1988, de 8 de junio, FJ 2. ${ }^{\circ}$, y 171/1990, de 12 de noviembre, FJ 9. ${ }^{\circ}$

${ }_{88}$ ATC 40/1999, de 22 de febrero, FJ 2. ${ }^{\circ}$

89 B. AlÁEZ CORRAL, «El ideario educativo constitucional como fundamento de la exclusión de la educación diferenciada por razón de sexo de la financiación pública», REDC, núm. 89 (2009), pp. 35 y ss.

${ }^{90}$ Como aprecia Vega Gutiérrez, «la definición de diversidad en el ámbito educativo estaría asociada a estudiantes diferenciados debido a alguna característica que la educación plantea como relevante (género, cultura, nivel de conocimiento, capacidad, motivación, expectativas, autoconcepto, etc.) en cuanto que se relaciona con la forma de aprender o con los resultados educativos». Cfr. A. M. VeGA GuTIÉRREZ, «La diversidad...», op. cit., p. 37.

${ }^{91}$ G. SuÁrez Pertierra, «Reflexiones acerca de la relación entre libertad de enseñanza e ideario de centro educativo», Anuario de Derechos Humanos, núm. 2 (1983), p. 640. 
respetuosos con la igual libertad ideológica de todos los alumnos dentro de los límites impuestos por el debido respeto a los derechos y deberes de los demás y al orden público constitucional protegido por la ley (arts. 16.1 CE y 3.1 LOLR) ${ }^{92}$. Los alumnos del centro son «titulares plenos [...] de sus derechos a la libertad de creencias y a su integridad moral» ${ }^{93}$, cuyo respeto en el interior de los centros docentes exige «la posibilidad jurídicamente garantizada de acomodar el sujeto su conducta religiosa y su forma de vida a sus propias convicciones [...] frente a otras personas o grupos sociales» ${ }^{94}$.

La laicidad positiva constituye, en suma, el elemento integrante del ideario educativo constitucional que garantiza el pluralismo ideológico y cultural en las aulas, en consonancia con la doctrina del TC de que en un «sistema jurídico político basado en el pluralismo, la libertad ideológica y religiosa de los individuos, y la aconfesionalidad del Estado, todas las instituciones públicas y, muy especialmente, los centros docentes, han de ser, en efecto, ideológicamente neutrales» ${ }^{95}$. «La neutralidad ideológica de la enseñanza en los centros escolares públicos [...] impone a los docentes que en ellos desempeñan su función una obligación de renuncia a cualquier forma de adoctrinamiento ideológico, que es la única actitud compatible con el respeto a la libertad de las familias que, por decisión libre o forzadas por las circunstancias, no han elegido para sus hijos centros docentes con una orientación ideológica determinada y explícita» ${ }^{96}$.

92 BOE, núm. 177, de 24 de julio de 1980.

93 «Dentro del marco de los principios constitucionales, del respeto a los derechos fundamentales, del servicio a la verdad, a las exigencias de la ciencia y a las restantes finalidades necesarias de la educación mencionadas, entre otros lugares, en el art. 27.2 de la Constitución [...] ajustándose a los mínimos que los poderes públicos establezcan respecto de los contenidos de las distintas materias, número de horas lectivas, etc.». Cfr. STC 141/2000, de 29 de mayo, FJ 5. ${ }^{\circ}$

${ }_{94}$ ATC 551/1985, de 24 de julio, FJ 3. ${ }^{\circ}$ En similares términos vid. ATC 617/1984, de 31 de octubre, FJ 4. ${ }^{\circ}$; SSTC 24/1982, de 13 de mayo, FJ $1 .^{\circ} ; 19 / 1985$, de 13 de febrero, FJ 2. ${ }^{\circ}$; 120/1990, de 27 de junio, FJ 10; 137/1990, de 19 de julio, FJ 8. ${ }^{\circ} ; 166 / 1996$, de 28 de octubre, FJ 2. ${ }^{\circ}$; 46/2001, de 15 de febrero, FJ 4. ${ }^{\circ} ; 154 / 2002$, de 18 de julio, FJ 8. ${ }^{\circ} ; 101 / 2004$, de 2 de junio, FJ $3 .^{\circ}$; 296/2005, de 21 de noviembre, FJ 4..$^{\circ}$; 34/2011, de 28 de marzo, FJ 3. ${ }^{\circ}$; 207/2013, de 5 de diciembre, FJ 5. ${ }^{\circ}$, y 51/2011, de 14 de abril, FJ 7. ${ }^{\circ}$

95 STC 5/1981, de 13 de febrero, FJ 9. ${ }^{\circ}$ y ATC 359/1985, de 29 de mayo, FJ 3. ${ }^{\circ}$

${ }^{96}$ STC 5/1981, de 13 de febrero, FJ 9. ${ }^{\circ}$ 


\section{LAICIDAD POSITIVA Y SIMBOLOGÍA RELIGIOSA Y CULTURAL EN LOS CENTROS DOCENTES PÚBLICOS}

\section{Delimitación conceptual: símbolos culturales y símbolos religiosos}

La presencia de representaciones simbólicas religiosas o culturales en los centros docentes públicos es uno de los retos actuales de la laicidad positiva como garantía institucional del ordenamiento constitucional en vigor, cuyo análisis no es pacífico en la doctrina ${ }^{97}$. Ahora bien, la gran

${ }^{97}$ Entre otros vid. D. LlamaZares FernánDEZ, «Derecho de la libertad de conciencia y simbología religiosa en la jurisprudencia del TEDH», en V. Gimeno SENDRA y M. T. RegueIRO GARCía (coords.), Nuevas tendencias en la interpretación de los derechos fundamentales, Madrid, Universitas, 2015, pp. 147 y ss.; M. C. Llamazares CAlZadilla, «Símbolos religiosos y Administraciones Públicas: el problema en las aulas de centros docentes públicos», en D. Llamazares Fernández (dir.), Libertad de conciencia y laicidad en las instituciones y servicios públicos, Madrid, Dykinson, 2009, pp. 277 y ss.; íD., «La presencia de símbolos religiosos en las aulas de centros públicos docentes», en J. MARTíNEz TORRÓN (dir.), La libertad religiosa y de conciencia ante la justicia constitucional, Granada, Comares, 1998, pp. 559 y ss.; A. Torres GutiérReZ, «Neutralidad del Estado y empleo de los símbolos religiosos en centros públicos en Alemania: la Sentencia del Tribunal Constitucional alemán de 24 de septiembre de 2003», Laicidad y libertades. Escritos jurídicos, núm. 5, fasc. 2 (2005), pp. 295 y ss.; J. WeILER, «El crucifijo en las aulas: la libertad de religión y libertad frente a la religión», Scripta Theologica, vol. 44 (2012), pp. 187 y ss.; A. Ruzz MigueL, «Libertad religiosa, símbolos religiosos...», op. cit., pp. 79 y ss.; B. Aláez CoRRAL, «Reflexiones jurídico-constitucionales sobre la prohibición del velo islámico integral en Europa», en I. GUTIÉRREz GUTIÉRREZ y M. A. PRESNO (eds.), La inclusión de los otros: símbolos y espacios de la multiculturalidad, Granada, Comares, 2012, pp. 121 y ss.; íD., «Reflexiones jurídico-constitucionales sobre la prohibición del velo islámico integral en Europa», Teoría y Realidad Constitucional, núm. 28 (2011), pp. 483 y ss.; J. RuIz Ruiz, «La prohibición del velo islámico en centros públicos de enseñanza y el orden público constitucional español y europeo», en M. REVENGA SÁNCHEZ, G. Ruiz-Rico y J. Ruiz Ruiz (dirs.), Los símbolos religiosos en el espacio público, Madrid, Centro de Estudios Políticos y Constitucionales, 2011, pp. 77 y ss.; C. Ruiz-Rico RuIz, «Símbolos religiosos e inmigración desde la perspectiva del derecho a la igualdad», en M. REvENGA SÁNCHEZ et al., Los símbolos religiosos en el espacio público, Madrid, Centro de Estudios Políticos y Constitucionales, 2011, pp. 299 y ss.; P. MarTínez RuANo, «El principio democrático y el uso de símbolos religiosos por los poderes públicos», en M. RevEnga Sánchez et al., Los símbolos religiosos en el espacio público, Madrid, Centro de Estudios Políticos y Constitucionales, 2011, pp. 49 y ss.; M. PARDO LÓPEZ, «Símbolos religiosos y deber de neutralidad estatal: el supuesto de los crucifijos en las aulas como excusa para aproximarse a la relación entre Estado y religión», Anuario de Derecho. Universidad de Murcia, núm. 26 (2008), pp. 183 y ss.; P. PARDO PRIETO, «Laicidad y símbolos en los pronunciamientos judiciales», Revista Jurídica de Castilla y León, núm. 27 (2012), pp. 1 y ss.; M. MeléndeZ VALDES, «Reflexiones jurídicas entorno a los símbolos religiosos», Revista General de Derecho Canónico y Derecho Eclesiástico del Estado, núm. 24 (2010); íD., «Diversidad religiosa, símbolos religiosos y espacio público», en A. FERNÁNDEZ CoRONADO et al. (coords.), Libertad de conciencia, laicidad y Derecho, Madrid, Civitas Thomson Reuters, 2013, pp. 627 y ss.; C. MiRAnda AvenA, «Perspecti- 
mayoría de autores que se han ocupado del estudio de esta temática lo han hecho englobando bajo la categoría unitaria de «símbolos religiosos» multitud de objetos y realidades bien diferentes entre sí. Frente a esta ten-

vas sobre el velo islámico: especial referencia a la doctrina del margen de apreciación en la jurisprudencia internacional», Anuario de Derechos Humanos, vol. 11 (2010), pp. 13 y ss.; G. Moreno Botella, «Libertad religiosa y neutralidad escolar. A propósito del crucifijo y otros símbolos de carácter confesional», Revista Española de Derecho Canónico, vol. 58, núm. 150 (2001), pp. 189 y ss.; Y. GÓMEZ SÁNCHEZ, «El pañuelo islámico: la respuesta europea», Anuario de Derecho eclesiástico del Estado, núm. 28 (2012), pp. 143 y ss.; M. J. GutiéRREZ DEL MORAL, «A propósito del velo islámico ¿es posible una solución intercultural?», Revista General de Derecho Canónico y de Derecho Eclesiástico del Estado, núm. 24 (2010); S. CAÑAmares ArRIBAS, «Símbolos religiosos en un Estado democrático y plural», Revista de Estudios Jurídicos, núm. 10 (2010), pp. 57-78; íD., «Nuevos desarrollos en materia de simbología religiosa», Revista General de Derecho Canónico y Derecho Eclesiástico del Estado, núm. 24 (2010); ÍD., «El empleo de simbología religiosa en España», Boletín Mexicano de Derecho Comparado, núm. 116 (2006), pp. 317 y ss.; íD., Libertad religiosa, simbología y laicidad del Estado, Pamplona, Aranzadi, 2005; M. AlENDA SALINAS, «La presencia de símbolos religiosos en las aulas públicas, con especial referencia a la cuestión del velo islámico», Revista General de Derecho Canónico y Derecho Eclesiástico del Estado, núm. 9 (2005); J. M. ConTRREAs MAZARío y O. CELADOR ANGÓN, Laicidad, manifestaciones religiosas e instituciones públicas, Madrid, Fundación Alternativas, 2007, pp. 36 y ss.; F. SANTAMARÍA LAMBÁs, «La cuestión religiosa en el espacio público...», op. cit., pp. 189 y ss.; íD., «La simbología religiosa. Dinámica en los centros educativos en España», en A. FERNÁNDEZ CORONADO et al. (coords.), Libertad de conciencia, laicidad y Derecho, Madrid, Civitas-Thomson Reuters, 2014, pp. 667 y ss.; M. T. ReGueIRO GARCíA, «Símbolos, prácticas y manifestaciones públicas», en VVAA, Gestión pública del hecho religioso, Madrid, Dykinson, 2015, pp. 147 y ss.; J. FERREIRO GalguerRA, «Símbolos religiosos en la escuela pública; crucifijos en el aula y alumnos con el hiyab», en J. A. Souto Paz (dir.), Educación y libertad, Madrid, Dykinson, 2012, pp. 81 y ss.; B. Souto Galván, «El debate sobre simbología en la escuela pública», Laicidad y libertades. Escritos jurídicos, núm. 14, fasc. 1 (2014), pp. 117 y ss.; M. J. PAREJO GUZMÁN, «Pluralidad o diversidad religiosa, técnicas de gestión o armonización y símbolos religiosos en nuestro país», en A. FERNÁNDEZ CORONADO et al. (coords.), Libertad de conciencia, laicidad y Derecho, Madrid, Civitas-Thomson Reuters, 2014, pp. 649 y ss.; Y. GARCíA RuIZ, «Pluralidad religiosas, diversidad cultural y derechos de la mujer. Novedades jurisprudenciales en España», en M. T. REGUEIro García y S. Pérez Álvarez (dirs.), Gestión de la diversidad cultural en la sociedad española, Valencia, Tirant Lo Blanch, 2013, pp. 325 y ss.; íD., «Símbolos religiosos en espacios públicos: una aproximación jurisprudencial», en M. A. AÑon Roig y A. Solanes Corella (coords.), Construyendo sociedades multiculturales: espacio público y derechos, Valencia, Universidad de Valencia, 2011, pp. 185 y ss.; S. PÉREZ ÁlvAREZ, «Retos de la gestión de la diversidad cultural en el ámbito educativo francés. El caso del velo y del pañuelo islámicos», en M. T. REGUEIro García y S. Pérez Álvarez (dirs.), Gestión de la diversidad cultural en la sociedad española, Valencia, Tirant Lo Blanch, 2013, pp. 449 y ss.; íD., «Behind the Islamic Full Veil and Headscarf under the Framework of the Council of Europe», Revue Européenne du Droit Social, vol. 16, núm. 3 (2012), pp. 112 y ss.; íD., «Marco constitucional del uso del velo y del pañuelo islámico en la sociedad española contemporánea: ¿Señas de identidad ideológica y/o cultural?», Foro, núm. 13 (2011), pp. 139 y ss.; F. AMÉRIGO, «El uso del velo islámico en el Derecho español», Laicidad y libertades. Escritos jurídicos, núm. 13, fasc. 1 (2013), pp. 7 y ss., y F. AméRigo y J. D. Pelayo Olmedo, El uso de símbolos religiosos en el espacio público en el Estado laico español, Madrid, Fundación Alternativas, 2013. 
dencia, entiendo que la delimitación de la verdadera naturaleza religiosa o cultural del símbolo de que se trate es fundamental si queremos tratar de ofrecer una vía de solución a los conflictos a que pueden dar lugar en los centros docentes públicos.

Según el Diccionario de la Real Academia de la Lengua el término «símbolo» procede del latín «symbŏlus» y éste, a su vez, de la expresión grie-

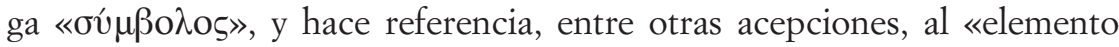
u objeto material que, por convención o asociación, se considera representativo de una entidad, de una idea, de una cierta condición». Por su parte, el TC los define como manifestaciones e iconos que «identifica(n) mejor a la institución representada o desempeña de manera más oportuna o conveniente la función integradora o representativa que todo símbolo comporta» ${ }^{98}$. En base a ambas definiciones podemos delimitar a grandes rasgos los símbolos culturales como aquellos que son comúnmente aceptados como representativos de las señas de identidad de una cultura determinada, mientras que los religiosos serían todos aquellos iconos u objetos percibidos y sentidos por la comunidad ideológica o religiosa de que se trate como representativos de su dogma de fe o culto.

Ahora bien, como advirtió Elliot a mediados del pasado siglo, la idea de «cultura» puede ser contemplada de manera diferenciada por un sujeto, una comunidad o la sociedad de la que el individuo o el grupo forman parte. De ahí que la noción de símbolo cultural hace referencia a los que representan ideas, valores y tradiciones que forman parte integrante del acervo cultural de la sociedad española en su conjunto considerada ${ }^{99}$. Y, en segundo término, cuando nos referimos a un símbolo cultural debemos tratar de depurar su representación en la conciencia social como manifestación cultural de su posible significación e identificación religiosa, pues no podemos olvidar que cualquier cultura hunde sus raíces en una determinada cosmovisión religiosa del mundo. Así sucede, por ejemplo, con la cultura española que desde finales del siglo iv ha estado influenciada por el cristianismo como religión oficial de Hispania en época del Imperio Romano y por el modelo de confesionalidad católica imperante en la historia del constitucionalismo español hasta la entrada en vigor de la CE de $1978^{100}$.

${ }^{98}$ STC 130/1991, de 6 de junio, FJ 5. ${ }^{\circ}$

99 T. S. Elliot, Notes towards the definition of culture, Oxford, Faber \& Faber, 1948, p. 1.

100 Todo ello sin olvidarnos de la influencia que ha tenido el Islam en algunas de las costumbres y las tradiciones que singularizan nuestra identidad nacional, si bien la influencia de la religión islámica como elemento de conformación de la cultura española ha sido muy pobre y hoy es casi inexistente, como consecuencia del restablecimiento del cristianis- 
La cuestión de la simbología es un auténtico banco de pruebas de esta realidad, más si tenemos en cuenta que la representación del imaginario que representan puede ser muy dispar de un sujeto y/o colectividad a otro y de todos con respecto al sentir generalizado de la sociedad. De ahí que, como afirman Fernández-Coronado y Suárez Pertierra, en la delimitación de esta cuestión es necesario «depurar de lo que hoy constituye elemento cultural el dato religioso que pudiera estar en su origen. De este modo, se transciende el valor religioso para dar relevancia, simplemente, al valor cultural que se ha generado de ese hecho, originariamente religioso, y que está desvinculado de la creencia identitaria» ${ }^{101}$.

Para llevar a cabo la labor de depuración de los símbolos culturales de su significación religiosa y de los símbolos religiosos entendidos como tales, nosotros proponemos aplicar la tesis de los paradigmas de Hans Küng. Según este autor, en todas las religiones universales existen «valores, convicciones, modos de proceder, etc.» ${ }^{102}$ que se constituyen en el pasado en el origen más remoto de cada religión. Los paradigmas religiosos se caracterizan por ser «supraindividuales, internacionales y transculturales», que permanecen inalterados en el devenir de la historia hasta el presente y que les permiten ser identificados en la representación social de todos los individuos y colectivos de la sociedad como elementos religiosos ${ }^{103}$. En base a esta teoría, entendemos que los símbolos que sean «representación sensorialmente perceptible» del paradigma de un determinado culto tendrán naturaleza religiosa ${ }^{104}$. En cambio, los símbolos culturales serían todos aquellos que, sin responder a los valores o dogmas paradigmáticos de una religión en el sentir social internacional, sean percibidos en el imaginario común de la sociedad española como representaciones de la cultura española ${ }^{105}$, aunque a veces incorporen elementos o datos de carácter

mo como elemento de cohesión territorial, primero, y de cohesión política y social desde la Reconquista culminada por los Reyes Católicos en 1492. Vid. J. VeRnet, Lo que Europa debe al Islam de España, Barcelona, El Acantilado, 1999, p. 43.

101 A. Fernández Coronado y G. SuÁrez Pertierra, Identidad social..., op. cit., p. 6.

${ }_{102}$ H. HüNG, El cristianismo. Esencia e historia, Madrid, Trotta, pp. 79 y ss.

${ }^{103}$ Ibid., pp. 126 y ss.

${ }^{104}$ Los símbolos representativos de una religión determinada son los que permitirían identificar aquellos que Miguel Ruiz califica como «símbolos religiosos en cuanto tales». Cfr. A. Ruiz Miguel, «Libertad religiosa, símbolos religiosos...», op. cit., p. 89. La tesis de los paradigmas religiosos de Hans Küng que hemos propuesto también serviría para individualizar los que Amérigo y Pelayo Olmedo consideran «símbolos institucionales». Cfr. F. AméRigo y J. D. Pelayo Olmedo, El uso de símbolos religiosos..., op. cit., p. 12.

${ }_{105}$ M. MÉLENDES VAldÉs, «Reflexiones jurídicas entorno...», op. cit., p. 7, e ÍD., «Diversidad religiosa...», op. cit., pp. 631-632. 
originariamente ideológico o religioso. Me refiero a todos aquellos iconos o manifestaciones que sean representativos «de la contribución histórica de los españoles a la civilización universal y de su capacidad creativa contemporánea» ${ }^{106}$ que hayan sido declarados o que, por sus características, puedan ser declarados «bienes de interés cultural».

En el ordenamiento jurídico español estos bienes se encuentran delimitados en el art. 1.2 de la Ley 16/1985, de 25 de junio, del Patrimonio Histórico Español, que se refiere a aquellos «objetos muebles de interés artístico, histórico, paleontológico, arqueológico, etnográfico, científico o técnico» y a los bienes que conforman el denominado «patrimonio cultural inmaterial». Según lo establecido en el art. 2 de la Ley 10/2015, de 26 de mayo, para la salvaguardia del Patrimonio Cultural Inmaterial ${ }^{107}$, ostentan esta consideración símbolos representativos de «los usos, representaciones, expresiones, conocimientos y técnicas que las comunidades, los grupos y en algunos casos los individuos reconozcan como parte integrante de su patrimonio cultural». En particular, los «usos sociales, rituales y actos festivos», los «conocimientos y usos relacionados con la naturaleza y el universo», y las «formas de socialización colectiva y organizaciones» que, como ha puesto de manifiesto el Comité de Derechos Sociales, Económicos y Culturales de la ONU, forman parte integrante de la cultura de un país o civilización determinada ${ }^{108}$. Siempre y cuando, eso sí, no se trate de símbolos representativos de paradigmas o dogmas de fe fundamentales «supraindividuales, internacionales y transculturales» que deben ser considerados como símbolos religiosos, pese a que pueden ser percibidos como elementos integrantes de la propia cultura en el imaginario común de la sociedad de que se trate ${ }^{109}$.

106 Preámbulo de la Ley 16/1985, de 25 de junio, del Patrimonio Histórico Español (BOE, núm. 155, de 29 de junio de 1985).

107 BOE, núm. 126, de 27 de mayo de 2015.

108 A. M. Vega GutiérReZ, «Diversidad, religión y cultura en la educación», en A. M. Vega GutiÉRREZ, (coord.) La gestión de la diversidad religiosa en el sistema educativo español, Cizur Menor, Aranzadi-Thomson Reuters, 2014, pp. 29 y ss.

109 Pues, como han puesto de manifiesto Fernández-Coronado y Suárez Pertierra: «Entendido en esa medida, estas prácticas culturales que incorporan ciertos datos religiosos no suponen un límite a la secularización, pues una sociedad puede estar muy secularizada e incorporar esas circunstancias desde la perspectiva de la identidad cultural. La prueba de esta afirmación es que muchas de estas prácticas no están dirigidas ni controladas por la propia Iglesia, sino que, por el contrario, proceden en alguna medida de la desvinculación progresiva de los dogmas religiosos por parte de los ciudadanos que, sin embargo, quieren mantener vivas ciertas prácticas de origen religioso que se han ido convirtiendo en usos sociales». Cfr. A. Fernández Coronado y G. Suárez Pertierra, Identidad social..., op. cit., p. 35. 
Una vez delimitados los parámetros para poder identificar la naturaleza cultural o religiosa del símbolo, vamos a analizar su posible uso en las escuelas públicas a la luz de las exigencias derivadas del debido respeto a las vertientes objetiva y subjetiva de la laicidad positiva ${ }^{110}$. Desde el punto de vista objetivo, centraremos nuestra atención en delimitar cuáles son los compromisos asumidos por el Estado con la laicidad con respecto al uso de símbolos religiosos o culturales de manera institucional en un centro docente público. Mientras que, bajo el prisma subjetivo, trataremos de verificar cuáles son las implicaciones de esta garantía institucional en relación con la utilización de los mismos por parte de los profesores y de los alumnos de los centros docentes públicos ${ }^{111}$.

\section{Vertiente objetiva de la laicidad positiva y uso institucional de símbolos culturales o religiosos en los centros docentes públicos}

El uso institucional de símbolos culturales o religiosos en las dependencias de los centros docentes públicos debe ajustarse a las exigencias derivadas de la dimensión objetiva de la laicidad positiva como garantía constitucional del ideario educativo constitucional, en orden a garantizar el derecho a formar en libertad y para la libertad la conciencia de los destinatarios de la acción educativa pública. Sobre todo, si tenemos en consideración que la presencia de este tipo de símbolos puede tener una gran influencia en este proceso psicológico interno de los alumnos del centro que carecen de la suficiente madurez o grado de discreción de juicio ${ }^{112}$. En este sentido, coincidimos con Llamazares Calzadilla cuando afirma que la presencia de los mismos en este tipo de instituciones se caracteriza por ser activa, «ya que el símbolo [...] está presidiendo la actividad educativa que tiene lugar en ese centro» ${ }^{113}$, al estar incorporando la idea o creencia o la seña de identidad

${ }^{110}$ En base al hecho de que los símbolos culturales y religiosos también tienen las mismas vertientes objetiva y subjetiva que esta garantía institucional. Vid. A. Ruiz Miguel, «Libertad religiosa, símbolos religiosos...», op. cit., p. 80.

${ }^{111}$ Nos referimos a los símbolos representativos de lo que calificamos como manifestaciones religiosas o prácticas o tradiciones culturales constitutivos de señas de identidad de una cultura o religión concreta. Vid. S. Pérez Álvarez, «Marco constitucional del uso del velo y del pañuelo islámico...», op. cit., pp. 140 y ss.

${ }_{112}$ J. ESCRIVÁ IVARS, «La importancia de la educación en familia para el desarrollo del menor», en I. M. BRIONES MARTínez (coord.), Educación en familia. Ampliando derechos educativos y de conciencia, Madrid, Dykinson, 2014, pp. 32 y ss.

${ }_{113}$ Cfr. M. C. Llamazares Calzadilla, «La presencia de símbolos religiosos...», op. cit., pp. $570-571$. 
que representa el icono o la imagen de que se trate como criterio que ordena la actividad del centro docente. La licitud o no del uso institucional del símbolo a la luz de la garantía institucional de la laicidad positiva vendrá determinada por la naturaleza religiosa o cultural del mismo.

\section{A) Uso institucional de simbolos religiosos}

Los símbolos religiosos son representativos de aquellos paradigmas «supraindividuales, internacionales y transculturales» que permanecen inalterados en el devenir de los tiempos y que les permiten ser identificados como característicos de una religión o ideología concreta en la representación social de todos los individuos y colectivos de la sociedad internacional. Así sucede, por citar algunos ejemplos, con la «media luna» islámica, la «estrella de David» judía, la «hoz y el martillo» comunista, la «esvástica» invertida del Tercer Reich, etc., que sirven para identificar a la ideología o religión que simbolizan en la comunidad internacional en cualquier periodo de tiempo dado. En el contexto educativo español, la influencia de la confesionalidad católica imperante en la historia de nuestro país en la enseñanza pública ha sido el factor determinante de que los símbolos religiosos que aún siguen siendo utilizados de manera institucional en algunos centros docentes públicos, representan paradigmas propios de la religión católica ${ }^{114}$.

La simbología es un elemento esencial del cristianismo ${ }^{115}$. La Biblia recoge multitud de iconos, representaciones e imágenes que sirven para individualizar a esta religión frente a las demás: la «Paloma» que representa al Espíritu Santo, la imagen «Virgen María» como madre de Dios o el «Crucifijo» como representación simbólica de Jesucristo, etc. Todos ellos son paradigmas de esta religión, en la medida que son iconos o imágenes que sirven para expresar y transmitir las verdades de este culto y el lenguaje iniciático por excelencia y vehículo indispensable de la enseñanza tradicional de esta religión ${ }^{116}$.

Por este motivo, se trata de iconos de naturaleza religiosa que, a mi juicio, nunca pueden ser considerados como representaciones «secularizadas»

114 J. FerReIro GalguerRa, «Símbolos religiosos...», op. cit., p. 107; F. SANTAMARÍa LamBÁS, «La cuestión religiosa en el espacio público...», op. cit., p. 193, y B. SOUto GaLván, «El debate sobre simbología...», op. cit., pp. 138 y ss.

115 J. Hani, Il simbolismo del templo cristiano, Roma, Arkeios, 1994, pp. 20 y ss.

116 R. GuÉnon, Il Simbolismo della Croce, Milano, Luni, 1998, pp. 14 y ss. 
que formen parte integrante de nuestro patrimonio histórico-cultural ${ }^{117}$. En este sentido, la Gran Sala del TEDH en el asunto Lautsi contra Italia ha dejado claro que no existe un consenso en Europa sobre la legitimidad de la presencia institucional de símbolos religiosos en las escuelas públicas. Los legisladores internos de los Estados miembros poseen un amplio margen de apreciación que disponen los poderes públicos nacionales para legislar o adoptar las decisiones que estimen pertinentes sobre esta materia ${ }^{118}$. En el caso concreto del crucifijo, aunque la Sala rectificó el pronunciamiento de primera instancia en relación con su carácter adoctrinante ${ }^{119}$, sí ratificó el criterio de que se trata de un símbolo que «reenvía inevitablemente al cristianismo» ${ }^{120}$, aunque «se le reconozca o no un valor simbólico laico» ${ }^{121}$ en el ordenamiento jurídico de que se trate, cuya presencia puede tener «un efecto sobre los jóvenes, cuyas convicciones todavía están por formarse» ${ }^{122}$.

En base a la doctrina del TEDH, las autoridades educativas españolas disponen de un amplio margen de apreciación para atribuir un cierto valor cultural a algunos símbolos religiosos católicos como el crucifijo ${ }^{123}$, si bien, ello no significa que formen parte de dicho patrimonio como «contribución histórica de los españoles a la civilización universal», que es, como dijimos, el criterio legal que nos permite identificar a los símbolos culturales en nuestro ordenamiento jurídico. Insistimos, todos los símbolos religiosos a que hace referencia la Biblia, y, entre ellos, el «crucifijo», constituyen paradigmas «supraindividuales, internacionales y transculturales» del cristianismo, y su presencia en las dependencias de los centros docentes públicos «funciona como una llamada, propone la fe que simboliza como un ejemplo e invita a seguir dicha fe. Además, en los niveles educativos inferiores se encuentran expuestos ante alumnos que, por su corta edad, no tienen aún concepciones fijas, no tienen formado su espíritu crítico y

${ }^{117}$ En contra de esta opinión Cañamares Arribas considera que el «crucifijo» es un símbolo secularizado que carece de carácter proselitista, debido a que, en su opinión, junto a su significado religioso posee otros aspectos de tipo cultural o histórico que los poderes públicos deben valorar positivamente. Vid. S. CAÑAMARES ARRIBAS, Libertad religiosa, simbología..., op. cit., p. 60, e ÍD., «Símbolos religiosos...», op. cit., p. 9.

118 Gran Sala, asunto núm. 30815/06, Lauitsi contra Italia, de 18 de marzo de 2011, N. 33, 26-28 y 70 .

119 B. Souto GALVÁn, «El debate sobre simbología...», op. cit., p. 135.

120 Asunto núm. 30815/06, Lauitsi contra Italia, de 3 de noviembre de 2009, N. 56, y Gran Sala, asunto núm. 30815/06, Lauitsi contra Italia, de 18 de marzo de 2011, N. 71. N. 71 .

${ }_{121}$ Gran Sala I, asunto núm. 30815/06, Lauitsi contra Italia, de 18 de marzo de 2011,

122 Ibid., núm. 66.

${ }^{123}$ M. MelÉndez Valdés, «Diversidad religiosa...», op. cit., pp. 647 y ss. 
no han aprendido a elaborar sus convicciones personales; por esa razón son personas particularmente influenciables» ${ }^{124}$ e incapaces de distinguir entre la posible significación cultural de este tipo de símbolos religiosos ${ }^{125}$.

En sentido similar, el TSJCyL ha constatado que «la presencia de cualesquiera símbolos religiosos (y también ideológicos o políticos) puede hacer sentir a los alumnos (especialmente vulnerables por estar en formación) que son educados en un ambiente escolar caracterizado por una religión en particular, suponiendo al Estado más próximo de una confesión que de otra, o simplemente más próximo al hecho religioso [...] circunstancia (que) puede ser emocionalmente perturbadora para el libre desarrollo de su personalidad y contraria al derecho de los padres a que sus hijos reciban una educación conforme a sus convicciones religiosas y/o morales» ${ }^{126}$. La naturaleza religiosa de estos símbolos, unido a su posible carácter adoctrinante, condiciona el margen de apreciación de que disponen las autoridades nacionales en esta materia ${ }^{127}$, pues en el ordenamiento constitucional español el uso institucional de este tipo de símbolos religiosos compromete la neutralidad ideológica que deben mantener las autoridades educativas de los centros docentes públicos según la doctrina del $\mathrm{TC}^{128}$, dada la significación religiosa y el carácter adoctrinante de este tipo de símbolos ${ }^{129}$. Las pautas interpretativas del Tribunal han quedado plasmadas en el art. 18 de la Ley Orgánica 8/1985, de 3 de julio, reguladora

124 Cfr. M. C. Llamazares Calzadilla, «La presencia de símbolos religiosos...», op. cit., p. 283. El argumento de la citada autora también ha sido asumido por Contreras Mazario y Celador Angón. Vid. J. M. Contreras Mazarío y O. Celador Angón, Laicidad, manifestaciones religiosas..., op. cit., p. 51.

125 A. Ruiz Miguel, «Libertad religiosa, símbolos religiosos...», op. cit., pp. 88 y ss.

126 STSJCyL 3250/2009, de 14 de diciembre, FJ 7. ${ }^{\circ}$

127 En la medida en que el margen de apreciación de los legisladores nacionales de los Estados parte del Consejo de Europa en relación con las materias sensibles para la ideología o conciencia de los ciudadanos se encuentra condicionado por los presupuestos constitucionales y valores éticos imperantes en la sociedad de que se trate. Vid. S. Pérez Álvarez, «El derecho del menor a ser educado conforme a su propia conciencia según los estándares del TEDH», Revista de Derecho Político, núm. 95 (2016), pp. 151 y ss.

128 En este sentido, el propio TC considera que la naturaleza religiosa del icono de que se trate afecta al compromiso asumido de mantener una actitud de neutralidad religiosa por imperativo de la aconfesionalidad estatal consagrada en el primer inciso del art. 16.3 CE. Vid. STC 34/2011, de 28 de marzo, FJ 4. ${ }^{\circ}$

129 Que en su vertiente objetiva «veda cualquier tipo de confusión entre funciones religiosas y estatales». Cfr. STC 24/1982, de 13 de mayo, FJ $1 .^{\circ}$ En sentido similar vid. SSTC 340/1993, de 16 de noviembre, FJ 3. ${ }^{\circ}$; 177/1996, de 11 de noviembre, FJ 9. ${ }^{\circ}$; 46/2001, de 15 de febrero, FJ 4. ${ }^{\circ}$; 154/2002, de 18 de julio, FJ 6. ${ }^{\circ}$; 101/2004, de 2 de junio, FJ 3. .'; 38/2007, de 15 de febrero, FJ 5. ${ }^{\circ}$; 128/2007, de 4 de junio, FJ 5. ${ }^{\circ}$; 34/2011, de 28 de marzo, FJ 3. ${ }^{\circ}$, y 51/2011, de 14 de abril, FJ 3. ${ }^{\circ}$ 
del derecho a la educación ${ }^{130}$, aún vigente, que establece que los «centros públicos desarrollarán sus actividades con sujeción a los principios constitucionales, garantía de neutralidad ideológica y respeto de las opciones religiosas y morales a que hace referencia el art. 27.3 de la Constitución».

En base a estas consideraciones, las autoridades educativas deberían remover todos aquellos símbolos representativos de los paradigmas doctrinales del cristianismo y de cualesquier otras religiones o ideologías ${ }^{131}$ por imperativo de la garantía institucional de la laicidad positiva, cuyo fin esencial es garantizar que en este tipo de centros tenga lugar la libre formación de la conciencia de los alumnos, sin que dicho proceso pueda estar influenciado por la presencia de iconos o representaciones religiosas en las aulas.

\section{B) Uso institucional de simbolos culturales}

En el ejemplo español, los símbolos culturales son todos aquellos que son percibidos en el imaginario común de la sociedad de que se trate como iconos representativos «de la contribución histórica de los españoles a la civilización universal y de su capacidad creativa contemporánea», ya sean de carácter material o inmaterial, como vimos con anterioridad. Atendiendo a la influencia que ha tenido el catolicismo en nuestra cultura, este tipo de símbolos pueden incorporar elementos o datos de carácter religioso, sin que este factor implique una desnaturalización de su naturaleza cultural, siempre que no sean representativos de dogmas de fe o valores paradigmáticos de esta religión en el sentido antes expuesto ${ }^{132}$, pues, como afirman Fernández-Coronado y Suárez Pertierra, este tipo de bienes materiales o inmateriales ya «no están dirigidos ni controlados por la Iglesia, sino que, por el contrario, proceden en alguna medida de la desvinculación progresiva de los dogmas religiosos» ${ }^{133}$ por parte de la con-

130 BOE, núm. 159, de 4 de julio de 1985.

${ }^{131}$ En este sentido vid., entre otros, J. M. Contrreas Mazarío y O. Celador Angón, Laicidad, manifestaciones religiosas..., op. cit., p, 51; M. T. REgueIro GarCíA, «Símbolos, prácticas...», op. cit., pp. 164 y ss.; A. RuIz Miguel, «Libertad religiosa, símbolos religiosos...», op. cit., pp. 94 y ss.; J. FerReIRO GALGUERRA, «Símbolos religiosos...», op. cit., p. 125; B. Souto GaLVÁN, «El debate sobre simbología...», op. cit., p. 136; M. C. LlamaZARES CAlZAdilla, «La presencia de símbolos religiosos...», op. cit., pp. 562 y ss.; P. MarTínez RuANO, «El principio democrático y el uso de símbolos...», op. cit., pp. 61 y ss.; F. SANTAMARía LAMBÁs, «La cuestión religiosa en el espacio público...», op. cit., p. 193, y B. ALÁEZ CORRAL, «Símbolos...», op. cit., pp. 109 y ss.

${ }^{132}$ A. Ruiz Miguel, «Libertad religiosa, símbolos religiosos...», op. cit., pp. 89 y ss.

133 Cfr. A. Fernández Coronado y G. SuÁrez Pertierra, Identidad social..., op. cit., p. 34. 
ciencia social española que, hoy por hoy, los percibe como elementos adentraros, a pesar de que para los creyentes sigan manteniendo una significación religiosa.

Así sucede, por citar algunos ejemplos, con la Cruz de Santiago; el escudo propio de algunas instituciones educativas como el de la Universidad de Salamanca, que contiene la imagen de un obispo; los bienes inmuebles que aún conservan una estructura arquitectónica y/o elementos ornamentales religiosos que actualmente constituyen la sede de una institución educativa pública, como acontece con el Colegio Público Santo Ángel de la Guarda; los patronos de algunas instituciones educativas o la celebración de festividades en nombre de ilustres religiosos como Santo Tomás de Aquino, etc. Todos ellos son «predominantemente culturales» ${ }^{134}$ de conformidad con la doctrina del TC, siempre que, insisto, no sean representativos del paradigma de una religión concreta. Pues, como considera el propio Tribunal, «no puede desconocerse que la materia sensible del símbolo [...] trasciende a sí misma para adquirir una relevante función significativa. Enriquecido con el transcurso del tiempo, el símbolo [...] acumula toda la carga histórica de una comunidad, todo un conjunto de significaciones que ejercen una función integradora y promueven una respuesta socioemocional, contribuyendo a la formación y mantenimiento de la conciencia comunitaria, y, en cuanto expresión externa de la peculiaridad de esa Comunidad, adquieren una cierta autonomía respecto de las significaciones simbolizadas, con las que es identificado; de aquí la protección dispensada a los símbolos [...] por los ordenamientos jurídicos» ${ }^{135}$.

Desde el punto de vista de la laicidad positiva como garantía institucional del ideario educativo constitucional, el uso institucional de los mismos en los centros docentes públicos debe realizarse de forma que las autoridades educativas transmitan que se trata de uno de los múltiples elementos que integran nuestro patrimonio cultural material e inmaterial. Y siempre que, además, por respeto al derecho a la diferencia, sean exhibidos en idénticas condiciones de establecimiento todos aquellos otros símbolos culturales que sean reclamados por los miembros de la comunidad escolar ${ }^{136}$. Dentro de estos límites, la presencia de los mismos en los centros

\footnotetext{
134 STC 34/2011, de 28 de marzo, FJ $4 .^{\circ}$

135 STC 94/1985, de 29 de julio, FJ $7 .{ }^{\circ}$

136 Cfr. J. M. Contreras Mazarío y O. Celador Angón, Laicidad, manifestaciones religiosas..., op. cit., p, 51.
} 
docentes públicos no es contraria a aquel principio $^{137}$, debido a que no compromete a la neutralidad ideológica del centro para garantizar el pluralismo religioso en las aulas, pues, insistimos, el respeto a la misma no implica que los poderes públicos deban renunciar necesariamente al uso de aquellos bienes o representaciones inmateriales que forman parte integrante del acervo que son expresión de la identidad del propio Estado ${ }^{138}$. Más bien todo lo contrario, la presencia de este tipo de iconos culturales puede contribuir muy positivamente al libre e integral desarrollo de la personalidad de todos los alumnos del centro, pues su identidad personal puede enriquecerse en contacto con otras identidades, individuales o grupales. El uso institucional de los mismos se ajusta a las exigencias derivadas en esta materia de la garantía institucional de la laicidad positiva en un contexto educativo como el español que está orientado, entre otros fines, a «la formación en el respeto y reconocimiento de la pluralidad lingüística y cultural de España y de la interculturalidad como un elemento enriquecedor de la sociedad» [art. 2.g) LOE] ${ }^{139}$. El respeto a la interculturalidad que representa la presencia de este tipo de símbolos culturales en las dependencias de la institución educativa se erige, entonces, como una exigencia derivada de vertiente objetiva de la laicidad positiva ${ }^{140}$ garante de una acción educativa pública que trata de promover la convivencia de todos los miembros de la comunidad escolar, en base a los principios de no discriminación e inclusión educativa como valores que también forman parte integrante del ideario educativo constitucional ${ }^{141}$.

137 A este respecto, el propio TC ha cuestionado que la presencia de elementos religiosos en un símbolo cultural como es el escudo originario de una institución docente universitaria que, por razones históricas, forma parte de nuestro acervo cultural pueda comprometer la garantía estacional de la aconfesionalidad estatal. Vid. STC 130/1991, de 6 de junio, FJ 5. ${ }^{\circ}$

${ }_{138}$ Sobre un análisis en profundidad del alcance y significado y consecuencias derivadas del principio de neutralidad como elemento funcional de la laicidad positiva vid. G. SuÁreZ PertiERRA, «La libertad ideológica, religiosa y de culto...», op. cit., p. 126.

139 S. PÉrez Álvarez, «Marco constitucional del uso del velo y del pañuelo islámico...», op. cit., pp. 174 y ss.

${ }^{140}$ La interculturalidad es una exigencia derivada de la garantía institucional de la laicidad positiva estatal en la medida en que constituye un modelo de gestión de la diversidad religiosa y/o cultural que efectúa una valoración positiva de la misma como realidad legitima y enriquecedora en base a una concepción dinámica y evolutiva de la cultura, lo cual propicia la convergencia y mestizaje de todas ellas en contextos sociales plurales como es la sociedad española contemporánea. Vid. A. M. VegA GuTIÉRREZ, «La diversidad religiosa en España...», op. cit., p. 50.

${ }^{141}$ B. Souto GALVÁN, «El debate sobre simbología...», op. cit., p. 140. 


\section{Vertiente subjetiva de la laicidad positiva y el uso de símbolos como manifestaciones de las señas de identidad religiosas y/o culturales en los centros docentes públicos}

Los símbolos religiosos y/o culturales tienen una dimensión subjetiva $^{142}$ en el sentido de que, como señala Llamazares Fernández, pueden ser utilizados por las personas como manifestaciones externas de sus convicciones religiosas o como expresión de sus señas de identidad cultural ${ }^{143}$. Nos referimos a objetos como cadenas, anillos y otros adornos o vestimentas como gorros para cubrir la cabeza como la kippah, turbantes, túnicas, vestidos ceremoniales, etc., símbolos que para quienes los utilizan pueden tener una significación religiosa y/o cultural y que son utilizados legítimamente en el ordenamiento jurídico español al amparo de la libertad ideológica y los derechos a decidir sobre la propia imagen ${ }^{144} \mathrm{o}$ a la identidad cultural ${ }^{145}$ por parte de quienes los utilizan, salvo que en el caso concreto existan razones de orden público constitucional que condicionen de manera puntual el uso de los mismos.

Así sucede, precisamente, en el contexto escolar, en el que la utilización de símbolos religiosos y culturales se encuentra condicionada por el debido respeto de los derechos de los discentes del centro y, muy especialmente, de su derecho al libre desarrollo de la personalidad como fin esencial del ideario educativo constitucional español. En la práctica española, las situaciones más conflictivas que se han planteado en esta materia atañen al uso del pañuelo y el velo integral islámico por parte de algunas profesoras y alumnas musulmanas en centros docentes públicos ${ }^{146}$. A este respecto debemos puntualiza que, como vengo defendiendo con anterioridad, el pañuelo islámico sí es una vestimenta cuyo uso es uno de los paradigmas que sirven para identificar a la religión islámica, en la medida en que se trata de una práctica desde la pubertad que hunde sus raíces en las fuentes primigenias del Derecho islámico y que, en las sociedades secu-

\footnotetext{
142 A. Ruiz Miguel, «Libertad religiosa, símbolos religiosos...», op. cit., p. 80.

143 D. Llamazares FernánDEZ, «Derecho de la libertad de conciencia y simbología...», op. cit., p. 182.

144 S. PÉrez Álvarez, «Marco constitucional del uso del velo y del pañuelo islámico...», op. cit., pp. 156 y ss.

145 A. CASTRO Jover, «Inmigración, pluralismo religioso y cultural y educación», Laicidad y libertades. Escritos jurídicos, núm. 2 (2002), pp. 111 y ss., y J. M. Contreras Mazarío y O. Celador Angón, Laicidad, manifestaciones religiosas..., op. cit., p, 40.

146 B. Souto Galván, «El debate sobre simbología...», op. cit., pp. 138 y ss.
} 
larizadas como la nuestra, es utilizada como manifestación de una convicción religiosa o como seña de identidad cultural que hunde sus raíces en su profundo significado religioso. Por ello precisamente, la utilización de este tipo de prendas se encuentra amparada en la libertad ideológica o de conciencia de la mujer que las viste. En cambio, el uso de las vestimentas que cubren por completo el rostro de la mujer salvos los ojos y que se denominan de manera general como «velo integral» responde a una interpretación, intencionada y en sí misma discriminatoria, de algunos mandatos de la revelación divina por parte de algunos movimientos fundamentalistas islámicos que sirvieron, a su vez, como sustrato ideológico para imponer el uso coactivo de estas prendas de vestir a las mujeres que residen en algunos países musulmanes. Así pues, la obligación de cubrir el rostro con alguna clase de velo no constituye, consecuentemente, una manifestación de la libertad de conciencia de la mujer que lo usa cuando reside en sociedades democráticas e ideológica y culturalmente plurales. Las mujeres musulmanas que, voluntariamente, deciden vestir con ambas clases de velo estarían ejercitando su derecho a la propia apariencia externa ${ }^{147}$ que, como ha dado a entender el $\mathrm{TC}^{148}$, forma parte integrante del derecho a la imagen como una forma de expresar externamente la dimensión moral de la persona ${ }^{149}$.

\section{A) El uso de símbolos religiosos y culturales por parte de los profesores de los centros docentes públicos}

A modo de principio general, la neutralidad ideológica como elemento funcional de la garantía institucional de la laicidad positiva impediría que los profesores de los centros docentes públicos puedan portar visiblemente símbolos o vestimentas religiosas en el desempeño de sus funciones discentes $^{150}$, atendiendo al posible adoctrinamiento que puede implicar, direc-

147 A. CASTRO Jover, «Inmigración, pluralismo religioso-cultural...», op. cit., p. 111.

148 STC $170 / 1987$ de 30 de octubre, FJ 4. ${ }^{\circ}$

149 S. Pérez Álunarez, «Marco constitucional del uso del velo y del pañuelo islámico...», op. cit., pp. 145 y ss., e í́., «Retos de la gestión de la diversidad cultural en el ámbito educativo francés...», op. cit., pp. 467 y ss. Distinción que posteriormente ha sido asumida por otros autores. Vid. F. AmÉRIGO, «El uso del velo islámico...», op. cit., pp. 7 y ss., y F. AmÉRIGo y J. D. Pelayo Olmedo, El uso de símbolos religiosos..., op. cit., pp. 44 y ss.

150 B. Aláez Corral, «Símbolos...», op. cit., pp. 109 y ss.; M. J. GutiérRez del Moral, «A propósito del velo islámico...», op. cit., p. 15, y M. Alenda SALINAS, «La presencia de símbolos religiosos...», op. cit., p. 18. 
ta o indirectamente, el uso de este tipo de objetos o vestimentas frente a los alumnos ${ }^{151}$, debido a que constituyen paradigmas de la ideología o religión a la que representan, como sucedería, por ejemplo, con el pañuelo islámico o con una cruz católica o estrella de David colgada al cuello. Sin embargo, desde el punto de vista de la dimensión subjetiva de aquella garantía institucional, las autoridades educativas deben respetar la libertad ideológica o de conciencia de los profesores que deciden voluntariamente utilizar este tipo de iconos o vestimentas como una manifestación de sus propias creencias en las dependencias de los centros docentes públicos. Siempre y cuando, eso sí, ello no lesione los derechos y libertades de los destinatarios de sus enseñanzas, esto es, siempre que los utilicen de forma personal y sin que ejerzan ninguna influencia en la libre formación de la conciencia de los discentes.

El debido respeto a este derecho implica que los maestros del ciclo formativo de Educación Infantil no deberían utilizar símbolos religiosos visibles ante los destinatarios de sus enseñanzas, pues «constituye la etapa educativa con identidad propia que atiende a niñas y niños desde el nacimiento hasta los seis años» ${ }^{152} \mathrm{y}$, por razón de su minoría de edad, son muy influenciables por el significado simbólico que poseen este tipo de objetos o vestimentas religiosas ${ }^{153}$. En efecto, durante los primeros años de vida se sientan los cimientos éticos o morales de la persona, la arcilla con la cual se puede amoldar su conciencia personal como consecuencia de su respuesta emocional a imágenes, símbolos o iconos externos que van a condicionar su inclinación hacia un tipo de convicciones u otras ${ }^{154}$. Poco a poco, los menores de estas edades comienzan a disfrutar, incipientemente, de un cierto sentido propio y autónomo de su propia conciencia en relación con la toma de aquellas decisiones que atañen a sus representaciones mentales de la realidad y comienza a conformar su propia identidad ${ }^{155}$. El proceso

${ }^{151}$ En la medida en que «los docentes desempeñan una doble función en el contexto educativo, una relacionada con la mera transmisión de contenidos docentes y otra relacionada con el papel que desempeñan, en cuanto educadores, en la formación de la conciencia de los alumnos». Cfr. J. M. Contreras Mazarío y O. Celador Angón, Laicidad, manifestaciones religiosas..., op. cit., p, 43.

152 Art. 12.1 de la Ley Orgánica 2/2006, de 3 de mayo, de Educación, tal y como ha sido reformada por obra de la Ley Orgánica 8/2013, de 9 de diciembre, para la Mejora de la Calidad Educativa (en adelante LOE). Vid. BOE, núm. 106, de 4 de mayo de 2006, y núm. 295, de 10 de diciembre de 2013, respectivamente.

153 D. Llamazares FernánDEZ, «Derecho de la libertad de conciencia y simbología...», op. cit., p. 182.

${ }^{154}$ J. EsCRIVÁ IVARS, «La importancia de la educación en familia...», op. cit., pp. 32 y ss.

155 S. PÉrez ÁlvareZ, «El derecho del menor a ser educado conforme a su propia conciencia...», op. cit., pp. 161 y ss. 
psicológico interno que tiene lugar durante la incipiente formación de la conciencia de los infantes de estas edades puede recibir una fuerte influencia del significado ideológico o religioso del símbolo que pudiera utilizar el maestro como manifestación externa de sus propias convicciones, por lo que no debería utilizarlo de manera visible ante los alumnos. Todo ello por imperativo de la garantía institucional de la laicidad positiva que tiene por objeto garantizar, en este caso, el derecho al libre desarrollo de la personalidad de los niños que atienden este tipo de enseñanzas en guarderías u otros centros docentes públicos.

A semejantes conclusiones llegamos con respecto al uso de este tipo de objetos o manifestaciones visibles de religiosidad en el ciclo de Educación Primaria Obligatoria, «que comprende seis cursos académicos que se cursarán ordinariamente entre los seis y los doce años de edad» y que persigue como finalidad esencial «facilitar a los alumnos y alumnas los aprendizajes $[\ldots]$ y el hábito de convivencia [...] con el fin de garantizar una formación integral que contribuya al pleno desarrollo de la personalidad de los alumnos y alumnas» (art. 16.1 LOE). Durante este periodo de madurez personal, el niño agudiza sus capacidades cognoscitivas e intelectivas, cada vez es más consciente del mundo que le rodea y comienza a pensar, por sí mismo, de manera lógica. Los profundos cambios cognitivos que tienen lugar durante los últimos años de la niñez se van reflejando en la facultad del menor para disfrutar, progresivamente, de mayor grado de autonomía en el ejercicio de su libertad ideológica o de conciencia, como sujeto activo, participante y creativo que, paulatinamente, va adquiriendo mayor madurez y discreción de juicio para desarrollar, autónomamente, su personalidad en el entorno social que le rodea en la búsqueda y satisfacción de sus necesidades, y en la satisfacción de las necesidades de los demás. Todo ello como consecuencia de los sentimientos y emociones primarias que experimentan al relacionarse con otros semejantes ${ }^{156}$, sean o no de su misma edad ${ }^{157}$, tanto en el mundo analógico como en el mundo virtual ${ }^{158}$. En este periodo formativo, el uso de símbolos religiosos de forma visible

156 D. LlamaZares FernÁNDEZ, «Educación en valores y enseñanza religiosa en el sistema educativo español», en G. SuÁrez Pertierra y J. M. Contreras Mazario (coords.), Interculturalidad y educación en Europa, Valencia, Tirant Lo Blanch, 2005, pp. 400 y ss.

157 S. PÉrez Álvarez, «El derecho del menor a ser educado...», op. cit., pp. 171 y ss.

158 Sobre un análisis en profundidad de esta cuestión desde la perspectiva específica del derecho a la educación vid. J. García GutiérRez y A. Morato SÁnCHEZ, «El derecho a la educación del menor y la educación en derechos humanos a través de Internet», en S. PÉREZ Álvarez, L. Burguera Ameave y K. Paul Larrañaga (dirs.), Menores e Internet, Pamplona, Aranzadi-Thomson Reuters, 2013, pp. 233 y ss. 
por parte del profesorado puede seguir teniendo una clara influencia en el proceso de formación en y para la libertad ideológica o conciencia de los alumnos de los centros docentes públicos, por lo que el profesorado de este ciclo formativo no debería portarlos de manera visible delante de ellos, por imperativo de la laicidad positiva como garantía institucional del ideario educativo constitucional español.

Diferente es el caso de la utilización de este tipo de símbolos de manera visible por parte de los docentes que imparten su docencia en el ciclo formativo de Educación Secundaria Obligatoria, que «comprende cuatro cursos que se seguirán ordinariamente entre los doce y los dieciséis años de edad» con la finalidad primordial, a los efectos que más no interesan, de «formarles para el ejercicio de sus derechos y obligaciones en la vida como ciudadanos» (art. 22 LOE). La acción educativa propia de estos niveles ya no persigue como fin esencial formar en y para la libertad su propia conciencia, sino educar a los alumnos para que ejerzan con plenitud su libertad ideológica o de conciencia entre otros derechos, en base a su grado de madurez y discreción de juicio. En este sentido, el TC ha reconocido que un menor de más de doce años de edad puede tener el suficiente grado de madurez para adoptar, en base a su conciencia, todas aquellas decisiones que afectan a su propia salud personal en contra, incluso, de la voluntad de aquéllos ${ }^{159}$. Si el Tribunal reconoce el máximo grado de autonomía a los adolescentes de estas edades que tengan suficiente madurez y discreción de juicio en relación con la toma de decisiones concernientes a su propia salud deberían tenerla, al menos a priori, para entender el alcance y significado del icono o vestimenta que es utilizada visiblemente por el profesor como manifestación externa de sus propias creencias, sin que ello vaya a ejercer una clara influencia sobre el libre desarrollo de la personalidad de los adolescentes destinatarios de sus enseñanzas ${ }^{160}$. Así pues, a modo de principio general, los profesores que imparten docencia sí podrían desarrollar sus actividades educativas con vestimentas o símbolos que sean expresión de su identidad religiosa ${ }^{161}$, siempre que no sean utilizados con

159 STC 141/2000, de 19 de mayo, FJ 5.

160 Sobre todo, si se tiene en consideración que, como regla general, a partir de estas edades se presume la capacidad del adolescente para pensar de forma abstracta y ya es capaz, desde el punto de vista cognitivo, de analizar y enfrentarse a situaciones utilizando múltiples criterios a la vez. Vid. Y. CAÑato RodríGuez, «Etapas del ciclo vital», en G. Peña TORBAY et al. (eds.), Una introducción a la psicología, Caracas, Universidad Católica Andrés Bello, 2006, p. 76.

${ }^{161}$ J. M. Contreras Mazarío y O. Celador Angón, Laicidad, manifestaciones religiosas..., op. cit., p, 43. 
finalidad adoctrinante de los alumnos y que no sean elementos desestabilizadores del orden público o perturben el normal desarrollo de las clases de conformidad con la doctrina del TC ${ }^{162}$. Dentro de estos límites, las autoridades educativas deben respetar esta manifestación de la libertad ideológica del profesorado de este ciclo formativo, en la medida que su uso en estos casos no sería lesivo de los derechos de los alumnos garantizados por la laicidad positiva ${ }^{163}$ como garantía institucional del ideario educativo constitucional.

Frente a estas consideraciones, los docentes de los centros educativos públicos de todos los niveles educativos pueden desarrollar sus funciones docentes portando símbolos representativos del acervo cultural nacional o del de cualquier otro país o civilización, incorporen o no datos o elementos religiosos, como, por ejemplo, la Cruz de Santiago o un escudo. El debido respeto a la vertiente subjetiva de la laicidad positiva exigiría que las autoridades educativas del centro docente público de que se trate no sólo deben respetar la libre manifestación de sus señas de identidad cultural por parte del profesorado del mismo ${ }^{164}$, sino que se encuentran obligadas a remover todos los obstáculos que dificulten su uso en el interior de la institución educativa en base a un proyecto educativo intercultural ${ }^{165}$. Desde el punto de vista del respeto a la interculturalidad como exigencia derivada de la laicidad positiva, el uso de este tipo de símbolos o indumentarias culturales por parte del profesorado formaría incluso parte del proyecto educativo que deben llevar a cabo este tipo de instituciones de atención a la diversidad, en orden a promover la convivencia de todos los miembros de la comunidad escolar en base a los principios de no discrimi-

${ }_{162}$ En este sentido, el TC ha dejado claro que «en un sistema jurídico político basado en el pluralismo, la libertad ideológica y religiosa de los individuos, y la aconfesionalidad del Estado, todas las instituciones públicas, y muy especialmente los centros docentes, han de ser, en efecto, ideológicamente neutrales. Esta neutralidad, que no impide la organización en los centros públicos de enseñanzas de seguimiento libre para hacer posible el derecho de los padres a elegir para sus hijos la formación religiosa y moral que esté de acuerdo con sus propias convicciones (art. 27.3 de la Constitución), es una característica necesaria de cada uno de los puestos docentes integrados en el centro y no el hipotético resultado de la casual coincidencia en el mismo centro y frente a los mismos alumnos de profesores de distinta orientación ideológica cuyas enseñanzas se neutralicen recíprocamente. La neutralidad ideológica de la enseñanza en los centros escolares públicos regulados en la LOECE impone a los docentes que en ellos desempeñan su función una obligación de renuncia a cualquier forma de adoctrinamiento ideológico». Cfr. STC 5/1981, de 13 de febrero, FJ 9. ${ }^{\circ}$

163 J. M. Contreras Mazarío y O. Celador Angón, Laicidad, manifestaciones religiosas..., op. cit., p, 43.

164 C. ElíAs MéNDEZ, La protección del menor..., op. cit., pp. 148 y ss.

165 A. M. Vega GutiéRREZ, «La diversidad religiosa en España...», op. cit., pp. 50 y ss. 
nación e inclusión educativa como valores que también integran el ideario educativo constitucional ${ }^{166}$.

\section{B) El uso de símbolos religiosos y culturales por parte de los alumnos de los centros docentes públicos}

El uso por parte de los alumnos de los centros docentes públicos de símbolos o vestimentas tanto religiosas como culturales no sólo no es contrario a la laicidad positiva que informa el ideario educativo constitucional, sino más bien todo lo contrario. Las autoridades educativas deben permiten que los alumnos puedan llevar este tipo de iconos o vestimentas en las dependencias del centro por imperativo de la vertiente subjetiva de aquella garantía institucional, en tanto en cuanto manifestaciones externas de la libertad ideológica y/o el derecho a la identidad cultural de los mismos ${ }^{167}$. La defensa del uso de símbolos religiosa y culturales por parte de los alumnos se insertaría, además, en el enfoque intercultural también garantizado por el ideario educativo laico, contribuyendo a la formación de la conciencia de los estudiantes en base a la promoción del respeto y la aceptación intergrupal de todos ellos ${ }^{168}$. Siempre que se trate, eso sí, de objetos, iconos o indumentarias de naturaleza religiosa o cultural, no de vestimentas como el velo integral en cualquiera de sus formas o la esvástica invertida del Tercer Reich, representativas de ideologías fundamentalistas o discriminatorias que podrían repercutir negativamente sobre la libre formación de la conciencia y los demás derechos fundamentales de los demás alumnos matriculados en el centro. Dentro de estos límites, las autoridades educativas sólo podrían restringir el uso de objetos o vestimentas por parte de los alumnos para atender aquellas actividades que, por sus características, no pudieran desarrollar con normalidad con este tipo de símbolos religiosos o culturales ${ }^{169}$.

166 B. SOUTO GALVÁN, «El debate sobre simbología...», op. cit., p. 140.

167 J. M. Contreras Mazarío y O. Celador Angón, Laicidad, manifestaciones religiosas..., op. cit., p, 44.

168 A. M. VeGA GuTIÉRREZ, «La diversidad religiosa en España...», op. cit., p. 51.

169 S. Pérez Állvarez, «El derecho del menor a ser educado...», op. cit., pp. 171 y ss. 


\section{A MODO DE CONCLUSIÓN}

El reconocimiento sin cortapisas de la igual libertad ideológica de todos los ciudadanos y los flujos migratorios de nacionales de terceros Estados con señas de identidad diferenciadas ha dado lugar en el devenir de los tiempos a una sociedad española mucho más secularizada pero, al mismo tiempo, plural desde los puntos de vista ideológico y/o cultural; por tanto, han sido los factores determinantes de la interpretación evolutiva de este principio constitucional. Ya de entrada, por influencia de la nomenclatura empleada para conceptuar este principio en otros ordenamientos jurídicos de los entornos más cercanos, en 2001 el TC comenzó a referirse a la aconfesionalidad estatal en términos de laicidad positiva como expresiones sinónimas y no, en cambio, como categorías jurídicas diferenciadas. $\mathrm{Y}$ es que, a mi juicio, el paso de una expresión a otra es un claro reflejo de interpretación evolutiva de la CE y de su adecuación a la conciencia social española sobre el fenómeno social ideológico y cultural cada vez más plural. La realización efectiva de los derechos fundamentales en juego en condiciones de igualdad reales y efectivas ha provocado que la laicidad positiva estatal haya sido elevada a la categoría de garantía institucional que, como ha apreciado el citado Tribunal, no sólo hace referencia a aquellos institutos jurídicos y principios constitucionalmente protegidos que constituyen «elementos arquitecturales indispensables del orden constitucional» en nuestros días.

La laicidad positiva como garantía institucional posee una doble vertiente: una objetiva y otra subjetiva. La vertiente objetiva se identifica con el compromiso asumido por imperativo constitucional ante el fenómeno social ideológico y religioso, esto es: 1) la separación entre el Estado y las comunidades ideológicas que veta cualquier tipo de confusión por parte de los poderes públicos entre los fines estatales y los ideológicos o religiosos, y 2) la neutralidad ante el fenómeno social ideológico y religioso como garante de la igual libertad ideológica o de conciencia de los ciudadanos en un contexto social plural. Por su parte, la vertiente subjetiva es la relativa a la acción de la laicidad positiva con respecto a los derechos y libertades individuales en juego: el mantenimiento por parte de los poderes públicos de relaciones de cooperación con estos colectivos cuando sea y hasta donde sea necesario para garantizar y promover, en su caso, el pleno disfrute de la libertad ideológica de los ciudadanos. La consecución de este objetivo constituye, en suma, la esencia de esta garantía institucional del orden cons- 
titucional en vigor, en todos y cada uno de los espacios de la esfera o espacio público donde se proyectan o, en su caso, puedan proyectarse las convicciones de los ciudadanos como es el ámbito educativo.

El derecho a la educación no es otra cosa que «el derecho a formar en libertad y para la libertad la propia conciencia». Definición que ha sido ratificada por la doctrina del TEDH que la define como «el procedimiento total mediante el cual en cualquier sociedad los adultos inculcan a los más jóvenes sus creencias, hábitos y demás valores» con la finalidad primordial de promover el desarrollo y la formación del carácter y el espíritu de los alumnos, así como su autonomía personal. Nos hallamos ante la piedra angular del progreso de los pueblos, la variable estratégica de mayor transcendencia para abordar los retos del presente, para desarrollar el capital humano, para impulsar el desarrollo y el cauce instrumental para la conformación de la identidad personal del ser humano conforme a la propia conciencia. Y es aquí donde entra en juego el principio de laicidad positivo que, como dijimos, tiene por objeto esencial garantizar la igual libertad ideológica de todos los ciudadanos en un contexto plural, y por ello, precisamente, forma parte integrante del ideario educativo diseñado por la CE de 1978 que preside la acción educativa pública.

El debido respeto a este ideario laico o aconfesional implica que tanto la acción educativa como la ordenación de las infraestructuras y/o dependencias de los centros docentes públicos deben ajustarse a la defensa y, en su caso, promoción de la igual libertad ideológica de todos los alumnos del centro. Parámetro que debe ser tenido en consideración por parte de las autoridades educativas para enjuiciar la legitimidad de la presencia de símbolos en las dependencias de los centros docentes públicos en función de que se trate de iconos o representaciones de carácter religioso o cultural. La delimitación de esta naturaleza puede llevarse a cabo mediante la tesis de los paradigmas de Hans Kung. En base a esta teoría, entendemos que los símbolos que sean «representación sensorialmente perceptible» del paradigma de una religión determinada tendrán naturaleza de símbolos religiosos, independientemente de que por su notorio arraigo en la historia de una determinada sociedad también puedan formar parte integrante de su acervo cultural, como, por ejemplo, el crucifijo cristiano, la estrella de David judía, etc. En cambio, los símbolos culturales son todos aquellos que, sin responder a los valores o dogmas paradigmáticos de una religión, son percibidos en el imaginario común de la sociedad de que se trate como representaciones de su acervo cultural, aunque a veces incorpore elementos o datos de carácter originariamente ideológico o religioso. En el ejem- 
plo español, símbolos culturales son todos aquellos iconos representativos «de la contribución histórica de los españoles a la civilización universal y de su capacidad creativa contemporánea que hayan sido declarados o que por sus características puedan ser declarados bienes materiales o inmateriales de interés cultural», como, por ejemplo, la Cruz de Santiago o la celebración de festividades como santo Tomás de Aquino.

El uso institucional de símbolos religiosos en las dependencias de los centros docentes públicos, unido a su posible carácter adoctrinante para aquellos alumnos que carecen del grado de madurez suficiente para entender el alcance y significado de los mismos, compromete la neutralidad ideológica que deben mantener las autoridades educativas de los centros docentes públicos según la doctrina del TC. Por este motivo, las autoridades educativas deberían remover todos aquellos símbolos representativos de los paradigmas doctrinales del cristianismo de cualesquier otras religiones o ideologías. En cambio, el uso institucional de símbolos o iconos representativos de los múltiples elementos que integran nuestro patrimonio cultural material e inmaterial sí es compatible con el ideario educativo constitucional aconfesional o laico; siempre que, por presión del respeto al derecho a la diferencia, se exhiban en idénticas condiciones de establecimiento todos aquellos otros símbolos culturales que sean reclamados por los miembros de la comunidad escolar.

Por su parte, el uso de iconos o indumentarias religiosas por parte de los profesores de los centros docentes públicos se encuentra condicionado por el grado de madurez y discreción de juicio de los alumnos frente a quienes desempeñen sus labores docentes. Así, el proceso psicológico interno que tiene lugar durante la incipiente formación de la conciencia de los alumnos de los ciclos formativos de Educación Infantil y Primaria Obligatoria puede recibir una fuerte influencia del significado ideológico o religioso del símbolo, por lo que no deberían utilizarlo de manera visible ante los alumnos. Todo ello por imperativo de la garantía institucional de la laicidad positiva que tiene por objeto garantizar, en este caso, el derecho al libre desarrollo de la personalidad de los niños que atienden este tipo de enseñanzas en centros docentes públicos. Diferente es el caso de la utilización de este tipo de símbolos de manera visible por parte de los docentes que imparten sus enseñanzas en el ciclo de Educación Secundaria Obligatoria que es atendido por alumnos que, a modo de principio general, tienen el grado de madurez suficiente para entender el alcance y significado del símbolo que está siendo utilizado visiblemente por el profesor, sin que ello vaya a ejercer una clara influencia en la libre formación de su con- 
ciencia. Por este motivo, los docentes de este ciclo formativo sí podrían desarrollar sus funciones educativas portando este tipo de objetos o vestimentas, siempre que no sean utilizados con finalidad adoctrinante de los alumnos y que no sean elementos desestabilizadores del orden público o perturben el normal desarrollo de las clases. Igualmente, tanto ellos como los profesores de los demás niveles educativos del centro podrían utilizar de manera visible objetos o vestimentas que expresen sus propias señas de identidad cultural, sobre todo en el marco de un sistema educativo como es el español que está orientado, entre otros fines, a la formación en el respeto y reconocimiento de la pluralidad cultural de España y de la interculturalidad como un elemento enriquecedor de la sociedad.

Finalmente, el uso por los alumnos de los centros docentes públicos de símbolos o vestimentas tanto religiosas como culturales no sólo no es contrario a la garantía institucional de la laicidad positiva, sino más bien todo lo contrario, las autoridades educativas deben garantizar y, en su caso, deben remover los obstáculos que impidan el uso de los mismos por imperativo de la vertiente subjetiva de aquella garantía institucional, en tanto en cuanto manifestaciones externas de la libertad ideológica y/o el derecho a la identidad cultural de todos los alumnos del centro. El uso por parte de los alumnos de símbolos religiosos o culturales sólo podría quedar restringido para atender aquellas actividades que, por sus características, no pudieran desarrollar con normalidad con este tipo de objetos o prendas de vestir. Todo ello por imperativo de la garantía institucional de la laicidad positiva como garante del ideario educativo constitucional, cuya esencia consiste en garantizar y promover, en su caso, el derecho a formar en libertad y para la libertad la propia conciencia de los alumnos como actores principales del sistema educativo español. 